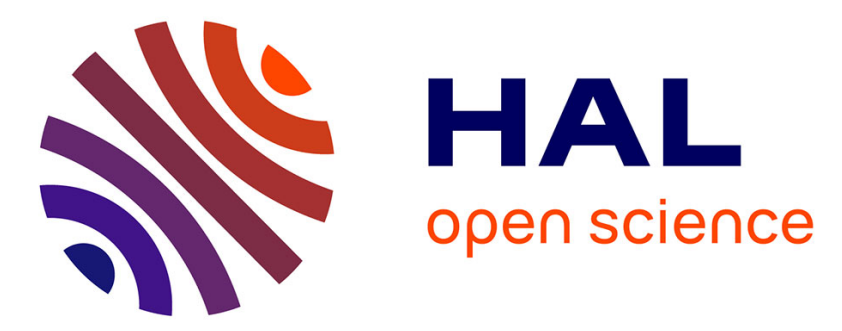

\title{
Pedogenic origin of precious opals from Wegel Tena (Ethiopia): Evidence from trace elements and oxygen isotopes
}

Boris Chauviré, Benjamin Rondeau, Anne Alexandre, Sarah Chamard-Bois, Carole La, Francesco Mazzero

\section{To cite this version:}

Boris Chauviré, Benjamin Rondeau, Anne Alexandre, Sarah Chamard-Bois, Carole La, et al.. Pedogenic origin of precious opals from Wegel Tena (Ethiopia): Evidence from trace elements and oxygen isotopes. Applied Geochemistry, 2019, 101, pp.127-139. 10.1016/j.apgeochem.2018.12.028 . hal02010828

\section{HAL Id: hal-02010828 \\ https://hal.science/hal-02010828}

Submitted on 23 Apr 2019

HAL is a multi-disciplinary open access archive for the deposit and dissemination of scientific research documents, whether they are published or not. The documents may come from teaching and research institutions in France or abroad, or from public or private research centers.
L'archive ouverte pluridisciplinaire HAL, est destinée au dépôt et à la diffusion de documents scientifiques de niveau recherche, publiés ou non, émanant des établissements d'enseignement et de recherche français ou étrangers, des laboratoires publics ou privés. 


\title{
Pedogenic origin of precious opals from Wegel Tena (Ethiopia): Evidence from trace elements and oxygen isotopes
}

\author{
Boris Chauviré ${ }^{\mathrm{a}, *}$, Benjamin Rondeau ${ }^{\mathrm{a}}$, Anne Alexandre ${ }^{\mathrm{b}}$, Sarah Chamard-Bois ${ }^{\mathrm{c}}$, Carole $\mathrm{La}^{\mathrm{c}}$, \\ Francesco Mazzero ${ }^{\mathrm{d}}$ \\ ${ }^{a}$ UMR-CNRS 6112: Laboratoire de Planétologie et Géodynamique de Nantes, 2 rue de la Houssinière, BP 92208, 44322, Nantes Cedex 3, France \\ ${ }^{\mathrm{b}}$ Université Aix-Marseille III, CNRS, IRD, CEREGE, Europôle de l'Arbois, BP 80, 13545, Aix en Provence Cedex 04, France \\ ${ }^{\mathrm{c}}$ UMR-CNRS 6112 Laboratoire de Planétologie et Géodynamique de Nantes, 2 rue de la Houssinière, BP 92208, 44322, Nantes Cedex 3, France \\ ${ }^{\mathrm{d}}$ Holaster 23 b rue de Kleindal, 57740, Longeville-lès-Saint Avold, France
}

\section{A R T I C L E I N F O}

Editorial handling by Prof. M. Kersten

Keywords:

Amorphous silica

Mineral deposits

Geochemistry

Oxygen isotopes

\begin{abstract}
A B S T R A C T
The trace element and oxygen isotope composition of Wegel Tena (Ethiopia) gem opals was measured to provide evidence of the conditions of their genesis. Elemental measurements display several behaviors, especially for $\mathrm{K}$, $\mathrm{Ca}, \mathrm{Sr}$ and Ba suggesting that-in agreement with previous assumptions-the silica-rich fluids that precipitate into opal are fed by the weathering of ignimbrite at several degrees. The distribution of elements in the opals indicates that the sources of silica in the ignimbrite are both glass and feldspar. Rare Earth Element (REE) signatures are also consistent with a weathering process, but underline that a wide range of physical and chemical conditions prevail at the regional, local and even intra-sample scales. The Ce anomaly emphasizes the variations in redox conditions during opal precipitation, whereas Eu anomaly indicates that feldspar dissolution feeds some of the silica-rich fluids. This suggests that the fluid responsible for opal precipitation is not homogenous across the area with underground water circulation, but rather that each sample reflects formation conditions specific to its very local environment. The oxygen isotope signatures of the opals (from 26.52 to $30.98 \%$ vs SMOW) allow us to formulate several hypotheses concerning their temperature of formation and the isotopic composition of the fluid. The hypothesis consistent with our other measurements is the pedogenic formation of the opals at ambient temperature $\left(18-21^{\circ} \mathrm{C}\right)$ involving a slightly evaporated soil water fed by meteoric water with an isotopic composition lower than at present, during an Oligocene period likely warmer and wetter than today.
\end{abstract}

\section{Introduction}

Opal, the hydrated amorphous variety of silica, commonly precipitates from silica-supersaturated fluids. Among opals, purely amorphous opal (opal-A) differs from poorly crystallized opal (opal-CT or -C) based on its atomic structure (Jones and Segnit, 1971; Ostrooumov et al., 1999; Smallwood et al., 1997). For both types of opal, three main formation processes have been identified: biological precipitation, hydrothermal alteration, and continental weathering. The main producers of biogenic silica are planktonic siliceous microorganisms (diatoms, radiolarians and silicoflagellates) accumulating in oceanic or lacustrine sediments at a rate that can be greater than $400 \mathrm{Mt}$ per year (DeMaster, 2014; Iler, 1979; Tréguer et al., 1995). Also, phytoliths can accumulate in soils (Meunier et al., 1999), although in much lower extent
(Alexandre et al., 1997, 2011; Conley, 2002; Fraysse et al., 2009). Therefore, biogenic opal is mostly constrained to oceanic and lacustrine contexts. Hydrothermal alteration is involved in amorphous silica precipitation in hot springs (e.g. geysers) and hydrothermal vents (e.g. black smokers; Arnórsson, 1985; Herzig et al., 1988; Lalou, 1991; Jones and Renaut, 2003; Goryniuk et al., 2004; Rodgers et al., 2004; Channing and Butler, 2007; Barnes et al., 2009; Campbell et al., 2015). Supergene, continental weathering of rocks also dissolves primary minerals and liberates silica available for the formation of secondary minerals, including opal (e.g. silcretes; Summerfield, 1979; Summerfield, 1983; Thiry and Millot, 1987; Thiry and Milnes, 1991; Thiry and Simon-Coinçon, 1996; Ullyott et al., 2004; Thiry et al., 2006).

The distinction between biogenic, hydrothermal, and continental weathering conditions may be ambiguous for opal samples in the field,

\footnotetext{
* Corresponding author.

E-mail addresses: Boris.chauvire@gmail.com (B. Chauviré), Benjamin.rondeau@univ-nantes.fr (B. Rondeau), alexandre@cerege.fr (A. Alexandre), sarah.chamard-bois@etu.univ-nantes.fr (S. Chamard-Bois), Carole.la@univ-nantes.fr (C. La), mazzero@holaster.fr (F. Mazzero).
} 
because paleontological features are not always preserved in biogenic opal, and because hydrothermal alteration and continental weathering can generate rocks that appear similar in aspect, texture outline and mineralogical composition. This is true on Earth, where silica is used to develop a better understanding of past climate history (Knauth and Epstein, 1976; Robert and Chaussidon, 2006), and even more striking on Mars, where observations are much more indirect (Frydenvang et al., 2017; Milliken et al., 2008; Mustard et al., 2008; Squyres et al., 2008). Hence, several opal properties have been explored as possible proxies of opal genesis conditions. Both opal-A and opal-CT form through hydrothermal alteration and continental weathering (Botz and Bohrmann, 1991; Goryniuk et al., 2004; Jones and Renaut, 2004; Murata and Randall, 1975; Rice et al., 1995). Hence, the type of opal (A or CT) is not of itself a useful criterion to infer its origin. Additionally, diagenesis can superpose on the original formation processes, leading to the transformation of opal-A into opal-CT, in particular for biogenic opal (Hein et al., 1978; Herdianita et al., 2000; Lynne et al., 2005; Lynne and Campbell, 2004; Rice et al., 1995; Rodgers et al., 2002). Recently, several tools based on hydration features of opals and their related infrared signatures (Chauviré et al., 2017a; Rice et al., 2013) have been proposed to differentiate hydrothermal opals from continental weathering opals, regardless of their structure (-A or -CT), From the economic point of view, a better understanding of precious opal formation may provide significant tools for gem opal exploration. A dozen deposits have been discovered in the Wegel Tena area, Ethiopia, within the last few years using small-scale, opportunistic, amateur exploration. Considering the extent of similar geologic formations in a wide part of the region, both in Ethiopia and adjacent countries (Fig. 1), one can assume a great potential for gem production. Hence, understanding the origin of the opals would help to systemize the identification of new deposits.

By accessing the source of elements and the processes involved in their transfer, geochemistry of trace elements and stable isotopes has proved to be a useful tool in understanding the formation of minerals as various as corundum (Giuliani et al., 2017; Harris et al., 2017; Sutherland et al., 2009), quartz (Götze et al., 2017; Monecke et al., 2002) and opal (Brown et al., 2004; Gaillou et al., 2008; Thomas et al., 2006). The geochemistry of opal has primarily been investigated on Australian opals, and showed that silica originates from the weathering of sedimentary and volcano-sedimentary rocks (Brown et al., 2004; Dutkiewicz et al., 2015; Gallacher, 2001; Liesgang and Milke, 2014; McOrist et al., 1994; McOrist and Smallwood, 1997; Rey, 2013; Thomas et al., 2006). Additionally, geochemical signatures of opals have been studied to discriminate different geographic and geological origins (Dutkiewicz et al., 2015; Gaillou et al., 2008). Gaillou et al. (2008) showed that opal follows a "pseudo-crystallochemistry" rule, despite its amorphous structure using a comprehensive sampling of opal with various origins and structures. They inferred that the isomorphous substitution of silicon $\left(\mathrm{Si}^{4+}\right)$ by trivalent aluminum $\left(\mathrm{Al}^{3+}\right)$ in the tetrahedral site is compensated by the contribution of divalent and monovalent ions (e.g. $\mathrm{Na}^{+}, \mathrm{K}^{+}, \mathrm{Mg}^{2+}, \mathrm{Ca}^{2+}, \mathrm{Ba}^{2+}$; Webb and Finlayson, 1987; Bartoli et al., 1990).

The oxygen isotope composition $\left(\delta^{18} \mathrm{O}\right.$, expressed hereinafter in $\%$ $v s$ VSMOW) of silica has also been used to trace the $\delta^{18} \mathrm{O}$ of the forming fluid and/or the formation temperature. Silica precipitated from hotspring or volcanic fluids is characterized by $\delta^{18} \mathrm{O}$ values ranging from 3 to 23\%o (Henderson et al., 1971; Jackson, 1977; Mizota et al., 1987; Vysotskiy et al., 2013) whereas authigenic silica precipitated from lowtemperature fluid have $\delta^{18} \mathrm{O}$ values ranging from 25 to $32 \%$ (Henderson et al., 1971; Murata et al., 1977; Pisciotto, 1981). A limited set of studies have investigated the $\delta^{18} \mathrm{O}$ of gem opals. Opals produced by continental weathering have $\delta^{18} \mathrm{O}$ values higher than $30 \%$, whereas hydrothermal opals show $\delta^{18} \mathrm{O}$ close to $13 \%$ (Martin and Gaillou, 2018; Rondeau et al., 2004; Vysotskiy et al., 2013).

Opals from Wegel Tena (Wollo province, Ethiopia) have been suggested to be of pedogenetic origin, hence related to continental weathering (Chauviré et al., 2017b; Mazzero et al., 2010; Rondeau et al., 2010, 2012). In this article, we document complementary evidence on the conditions of formation of these opals. Minor and trace elements will be compared with other precious opal deposits to characterize trends in the incorporation of elements during opal precipitation. The analysis of Rare Earth Elements (REE) will be used to trace the processes of elemental fractionation leading to the observed anomaly (especially Ce and Eu). The oxygen isotope composition of opals will provide constraints on their context of formation, especially the temperature of precipitation and the isotopic composition of the host fluid.

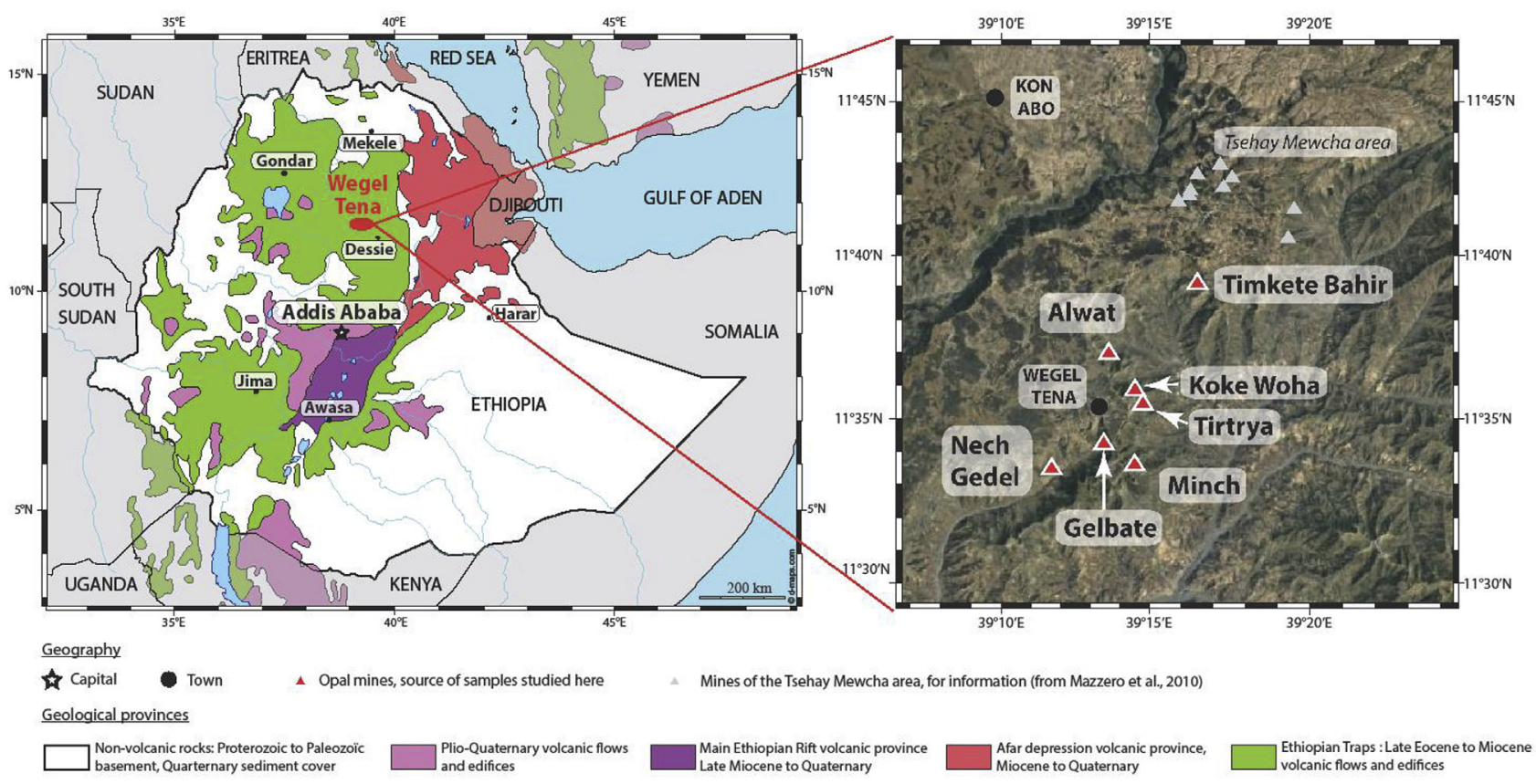

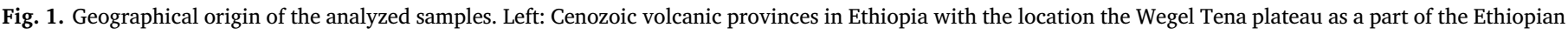
traps. Right: opal mines along the Wegel Tena plateau where samples were collected (GPS positions are available in Table 1). 


\section{Site description}

The precious opal deposits are located within a few specific layers of the Wegel Tena volcanic sequence, about $3000 \mathrm{~m}$ above sea level (Chauviré et al., 2017b; Rondeau et al., 2012). This sequence forms a plateau, with a surface area of $1600 \mathrm{~km}^{2}$, part of a larger Oligocene volcanic province, i.e. the Ethiopian traps $\left(6.10^{5} \mathrm{~km}^{2}\right.$; Baker et al., 1996; Hofmann et al., 1997; Rochette et al., 1998; Ayalew et al., 2002; Ukstins et al., 2002; Ayalew and Yirgu, 2003; Coulié et al., 2003). Geochronological and magnetostratigraphic data have determined that the emplacement of the whole volcanic sequence occurred between $30.6 \pm 0.79$ and $29.4 \pm 0.1$ million years ago (Ayalew et al., 2002; Ayalew and Yirgu, 2003; Coulié et al., 2003; Hofmann et al., 1997; Rochette et al., 1998; Ukstins et al., 2002). Like other parts of the Ethiopian traps, the Wegel Tena sequence is composed of rhyolitic ignimbrites and pyroclastic deposits (up to $1000 \mathrm{~m}$ thick) superimposed on a series dominated by basalts (Ayalew et al., 2002; Baker et al., 1996; Mohr, 1983; Pik et al., 1998). The acidic sequence is made of individual strata $3-15 \mathrm{~m}$ thick. The petrographic and geochemical characteristics of the Wegel Tena ignimbrites have been previously detailed (Ayalew et al., 2002; Ayalew and Yirgu, 2003). They have a porphyric texture with a vitreous to microlitic matrix. Alkali feldspars, quartz, clinopyroxene and amphibole are the common phenocrysts found in a potassic matrix. Bulk rock analysis revealed a rhyolitic, and more rarely trachytic, composition.

Wegel Tena opal (also referred to as Wollo opal) is found in few specific, remarkably weathered rhyolitic ignimbrite layers, a few meters thick and hundreds of meters wide, embedded between un-weathered layers. These opal-bearing horizons occur several hundreds of meters below the actual plateau surface (Chauviré et al., 2017b; Rondeau et al., 2012). No traces of fluid circulation or subsequent weathering are observed in the un-weathered, thick, welded layers above the opalbearing layers, constraining opal formation to the period after its hostrock deposition and before the overlying volcanic strata, and hence between 30.6 and $29.4 \mathrm{Ma}$ (Oligocene period).

The weathered layers show a granular microstructure with coatings of illuvial clays in the pores. Opal acts as a cement for these typical pedogenic features, suggesting opal precipitation concomitant with or posterior to pedogenesis. Opal also fills the remaining porosity or large, up to decimetric, cavities (see further details in Chauviré et al., 2017b). Therefore, opal formation is closely related to pedogenesis (Chauviré et al., 2017b; Rondeau et al., 2012). Plant fossils observed in Wegel Tena opals have been suggested as evidence that opal precipitates during pedogenesis (Rondeau et al., 2012). However, the type of silica composing the plant fossils and their well-preserved structure suggest that silicification of the plant occurred during the deposition of the ignimbrite, prior to the pedogenesis (Chauviré et al., 2017b). Chauviré et al. (2017b) modified the model proposed by Rondeau et al. (2012) by suggesting that opal may precipitate after the emplacement of ignimbrite above the soil, but the mineralogical and petrological evidence confirmed the pedogenetic source of silica-enriched fluids. Oxygen isotopes were measured on 3 samples of Wollo opal, giving $\delta^{18} \mathrm{O}$ from +26 to $+28 \%$, suggesting a relatively low temperature of formation (Vysotskiy et al., 2013). The superimposition of weathered and unweathered layers of rhyolitic ignimbrite suggests that the precipitation of opal could have been repeated over time during the emplacement of the Wegel Tena plateau around 30 My ago, during several periods between volcanic ash emissions (Chauviré et al., 2017b). Moreover, some unweathered layers superposed on the opal-bearing layer are highly welded, preventing later percolation of fluids. Based on these observations, the genetic model proposed by Chauviré et al. (2017b) suggests that opal precipitated shortly after the emplacement of the ignimbrite above the opal-bearing layer. No direct method exists for dating opal formation. The most recent indirect attempt is based on paleomagnetic methods applied to ironstone concretions hosting opal (Schmidt and Dickson, 2017), providing an age with a 7 My accuracy.
At Wegel Tena, the plentiful dating information given by the acidic rocks, which constrain the emplacement of the whole volcanic sequence within less than 2 My (Ayalew et al., 2002; Baker et al., 1996), and the demonstrable observation that opal precipitated during this time lapse (Chauviré et al., 2017b), provide a unique context in which dated opal formation can be studied.

Today, the climate of the Ethiopian highlands is monsoonal with a mean annual precipitation of $1250-1300 \mathrm{~mm}$ per year and a mean annual atmospheric temperature close to $16^{\circ} \mathrm{C}$ (Kebede and Travi, 2012; Viste et al., 2013). This is drier and cooler than the reconstructed Oligocene climate (García Massini et al., 2011; Jacobs et al., 2005). The vegetation is mainly constituted of woodland and grassland. The mean annual $\delta^{18} \mathrm{O}$ value of modern meteoric water $\left(\delta^{18} \mathrm{O}_{\text {meteoric water }}\right)$ is $0.04 \%$ at Dessie, the closest collecting station, about $70 \mathrm{~km}$ from Wegel Tena, at an altitude of $2400 \mathrm{~m}$ (IAEA/WMO, 2017).

\section{Materials and methods}

\subsection{Opal samples}

Twenty-nine opal samples, translucent to transparent, colorless to orange, were analyzed. The sample characteristics and origin are detailed in Table 1. Fourteen samples were collected in 2013 from seven mines located a few kilometers from Wegel Tena town $\left(11^{\circ} 35^{\prime} 20.3^{\prime \prime} \mathrm{N}\right.$; $39^{\circ} 13^{\prime} 16.5^{\prime \prime}$ E; Fig. 1). Each mine consists of several tunnels dug horizontally over a few meters to a few tens of meters (for details, see Chauviré et al., 2017b). Fifteen other samples were acquired from a merchant. They were confidently traced to the Wegel Tena mines, but no exact location was available. Among these 29 samples, 24 were used for elemental analyses (minor and trace) and 8 for oxygen isotope measurements (samples WT92, WT134 and WT149 were analyzed for both elemental and isotopic measurements).

\subsection{Element measurements}

Element concentrations were measured using Laser Ablation Induced Coupled Plasma- Mass spectroscopy (LA-ICP-MS), on 4 areas of the polished surface of 24 samples ( 9 samples directly collected in the mines, and 15 samples acquired). In order to check for possible internal variations, the analysis of each area was composed of 5 lines (each $65 \mu \mathrm{m}$ wide and about $300 \mu \mathrm{m}$ long). Analyses were carried out on a quadrupole Varian 820MS (line 68) with an Analyte G2 Excimer Laser Ablation System at $193 \mathrm{~nm}$ (Photon Machines, Cellule HelEx) at the Laboratoire de Planétologie et Géodynamique (UMR-6112, University of Nantes). Spot size was $65 \mu \mathrm{m}$ in diameter, the energy of the beam was $6.35 \mathrm{~J} / \mathrm{cm}^{2}$, and the laser pulse frequency was $10 \mathrm{~Hz}$ on polished sections. We used synthetic glass (NIST-612) as reference material to correct for instrument drift. Three measurements of the NIST standard were performed before and after each measurement run, and for every 4 lines of opal measurement. The instrumental drift was corrected with linear interpolation using the Glitter software.

Element concentrations were calculated with the Glitter software, using reference materials and Si concentration as internal standard. For the 9 samples collected directly in the mines, the Si content was measured using an electron probe micro-analysis Cameca SX100 at IFREMER, Brest, France. This instrumental reading was performed with a $\mathrm{LaB}_{8}$-filament at $15.5 \mathrm{kV}$. In addition, we measured the content of $\mathrm{K}$, $\mathrm{Na}, \mathrm{Al}$ and $\mathrm{Ca}$ in order to check for potential analytical correction. $\mathrm{U}$, Th and $\mathrm{Pb}$ have been measured only on these 9 samples. The Si content of the remaining samples was measured using an Energy Dispersive X-ray Spectroscopy SAMx instrument, coupled to a SEM JEOL 5800LV at the Institut des Matériaux Jean Rouxel, Nantes, France. Analyses were performed with an accelerating voltage of $20 \mathrm{kV}$ and a beam current of $0.5 \mathrm{nA}$. 
Table 1

Characteristics and origin of the samples used in this study.

\begin{tabular}{|c|c|c|c|}
\hline Samples & Color & $\begin{array}{l}\text { Mine } \\
\text { Latitude;Longitude }\end{array}$ & Host-rocks \\
\hline WT86 & Yellow transparent & Koke Woha & Highly weathered unwelded rocks, porphyric texture, quartz and feldspar xenocrysts, no remaining glass \\
\hline WT87 & Colorless transparent & $11^{\circ} 35^{`} 45.5^{\prime \prime} \mathrm{N} ; 39^{\circ} 14^{‘} 12.7^{\prime \prime} \mathrm{E}$ & shards, totally transformed into smectite. Granular microstructure with illuvial clay coating and \\
\hline WT92 & White translucent & & cementing by opal. \\
\hline WT103 & White translucent & Gelbate & \\
\hline WT107 & White translucent & $11^{\circ} 34^{\prime} 9.6^{\prime \prime} N ; 39^{\circ} 13^{`} 13.4^{\prime \prime} \mathrm{E}$ & \\
\hline WT109 & $\begin{array}{l}\text { Transparent colorless to } \\
\text { orange }\end{array}$ & & \\
\hline WT134 & White translucent & Minch & Well-sorted round grains (feldspar, quartz, amphibole and pyroxene crystals) cemented by amorphous \\
\hline WT149 & Colorless transparent & $11^{\circ} 33^{`} 44.4^{\prime \prime} N ; 39^{\circ} 13^{\prime} 47.9^{\prime \prime} E$ & silica, no glass shards remaining. \\
\hline WT150 & Brown to white & & \\
\hline WT159 & Colorless with brown zonation & $\begin{array}{l}\text { Alwat } \\
11^{\circ} 37^{\prime} 0.4^{\prime \prime} N ; 39^{\circ} 13^{\prime} 10.8^{\prime \prime} \mathrm{E}\end{array}$ & No details, rocks not accessible. \\
\hline WT171 & White translucent & Timkete Bahir & Highly weathered unwelded rocks, prophyric texture, quartz and feldspar xenocrysts. Glass shards \\
\hline WT176 & Colorless transparent & $11^{\circ} 39^{\prime} 15.7^{\prime \prime} N ; 39^{\circ} 16^{\prime} 2.7^{\prime \prime} \mathrm{E}$ & totally transformed into smectite. Granular microstructure with illuvial clay coating, and cementing by \\
\hline WT205a & White translucent & $\begin{array}{l}\text { Tirtrya } \\
11^{\circ} 36^{\prime} 29.7^{\prime \prime} N ; 39^{\circ} 13 ‘ 51.2^{\prime \prime} E\end{array}$ & opal. \\
\hline WT208 & White translucent & $\begin{array}{l}\text { Nech Gedel } \\
11^{\circ} 33^{\prime} 32.9^{\prime \prime} N ; 39^{\circ} 11^{\prime} 13.9^{\prime \prime} E\end{array}$ & $\begin{array}{l}\text { Rounded ferruginous nodules, in a fine-grained tuff with slightly weathered glass shards, some quartz } \\
\text { and feldspar xenocrysts. Opal found in cavities. }\end{array}$ \\
\hline SCB_50 & Light yellow transparent & Wegel Tena area & Weathered volcanoclastic rocks \\
\hline SCB_51 & Light orange transparent & & \\
\hline SCB_55 & Light yellow transparent & & \\
\hline SCB_56 & Yellow transparent & & \\
\hline SCB_57 & Yellow transparent & & \\
\hline SCB_59 & Yellow transparent & & \\
\hline SCB_62 & Yellow transparent & & \\
\hline SCB_64 & Yellow transparent & & \\
\hline SCB_66 & $\begin{array}{l}\text { Transparent from colorless to } \\
\text { orange }\end{array}$ & & \\
\hline SCB_70 & Yellow transparent & & \\
\hline SCB_72 & Yellow to white translucent & & \\
\hline SCB_75 & Orange transparent & & \\
\hline SCB_77 & $\begin{array}{l}\text { Translucent from light yellow } \\
\text { to white }\end{array}$ & & \\
\hline SCB_78 & $\begin{array}{l}\text { Yellow, translucent to } \\
\text { transparent }\end{array}$ & & \\
\hline SCB_79 & Translucent, orange to white. & & \\
\hline
\end{tabular}

\subsection{Oxygen isotope analyses}

The oxygen isotope composition was measured at CEREGE (UMR 7330, Aix-en-Provence, France), on 8 samples directly collected from the mines. The selected samples were transparent to translucent and white or colorless, to avoid the presence of iron oxy-hydroxide inclusions that give a yellow to red coloration to the opals (Fritsch et al., 2002, 1999; Gaillou et al., 2008). Each sample was crushed in an agate mortar and subsequently sieved at 50 and $150 \mu \mathrm{m}$. The powder was devoid of any mortar chalcedony contamination as checked on an aliquot using polarizing light microscopy. Pieces of opal with small inclusions were removed from the powder. The mortar was washed with Fontainebleau sand, water, and ethanol before crushing. One to two aliquots of the $50-100 \mu \mathrm{m}$ fraction were analyzed per sample.

Because opal is hydrated (up to $11 \mathrm{wt} \%$ water; Bayliss and Males, 1965; Segnit et al., 1965; Buerger and Shoemaker, 1972; Langer and Flörke, 1974; Thomas et al., 2010), it contains exchangeable oxygen that needs to be removed prior to analysis (Alexandre et al., 2006; Juillet-Leclerc and Labeyrie, 1987; Knauth and Epstein, 1982; Menicucci et al., 2017). Here, the samples were subjected to inert gas flow dehydration (Chapligin et al., 2010) to remove the exchangeable oxygen without fractionation: $1.6 \mathrm{mg}$ samples were dehydrated by ramp degassing (2h heating to $1020^{\circ} \mathrm{C}, 1.5 \mathrm{~h}$ held constant at $1020^{\circ} \mathrm{C}$, $2 \mathrm{~h}$ cooling down to $400{ }^{\circ} \mathrm{C}$ ) under a continuous $\mathrm{N}_{2}$ flow. Oxygen extraction was then performed using the IR laser-heating fluorination technique (Alexandre et al., 2006). The oxygen gas samples were sent to and analyzed by a dual-inlet mass spectrometer Thermoquest Finnigan Delta Plus . Measured $\delta^{18} \mathrm{O}$ values were corrected on a daily basis using a quartz laboratory standard (Boulangé $50-100 \mu \mathrm{m}$ ) calibrated on
NBS28 (Alexandre et al., 2006; Crespin et al., 2008). During the ana-

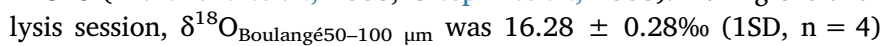
and one analysis of NBS28 gave a $\delta^{18} \mathrm{O}_{\mathrm{NBS} 28}$ of $9.72 \%$. The amorphous silica working standard MSG60 previously used for biogenic silica isotope analyses inter-laboratory comparison (MSG60: $37.0 \pm 0.8$; Chapligin et al., 2011) gave a $\delta^{18} \mathrm{O}$ value of $36.51 \pm 0.44 \%$. The standard deviation on the opal $\delta^{18} \mathrm{O}\left(\delta^{18} \mathrm{O}_{\text {opal }}\right)$ measurements replicates was better than $0.5 \%$ (from 0.03 to $0.46 \%$ ).

\section{Results}

\subsection{Minor and trace elements}

The elemental measurements of the 24 samples are presented in Table 1S (Supplementary Material). Aluminum is the most abundant minor element (from 0.22 to $2.22 \mathrm{wt} \%$ ), and other cations are also relatively abundant $(721<\mathrm{Ca}<8781 \mathrm{ppm}, 1573<\mathrm{K}<9185 \mathrm{ppm}$, $396<\mathrm{Na}<8497 \mathrm{ppm}$ ). Barium content is highly variable from one sample to another (from 33.52 to $2183 \mathrm{ppm}$ ), as well as zirconium (from 17.97 to $4103 \mathrm{ppm}$ ), iron (from 22.1 to $1413 \mathrm{ppm}$ ) and titanium (from 2.02 to $1842 \mathrm{ppm}$ ). Samples WT92 and WT109 are remarkably rich in barium and calcium compared to the other samples (e.g. they contain 1721 and $2182 \mathrm{ppm}$ of barium respectively, compared to a range of 33.5-179.7 ppm for the other samples).

The most common trace elements measured in the opals are strontium (from 14.17 to $579.2 \mathrm{ppm}$ ), manganese (up to $415.4 \mathrm{ppm}$ ), niobium (up to $169.4 \mathrm{ppm}$ ), rubidium (up to $67.86 \mathrm{ppm}$ ), and germanium (up to $26.68 \mathrm{ppm}$ ). Again, samples WT92 and WT109 display the highest trace element concentrations (e.g. 490 and $579.2 \mathrm{ppm}$ of 


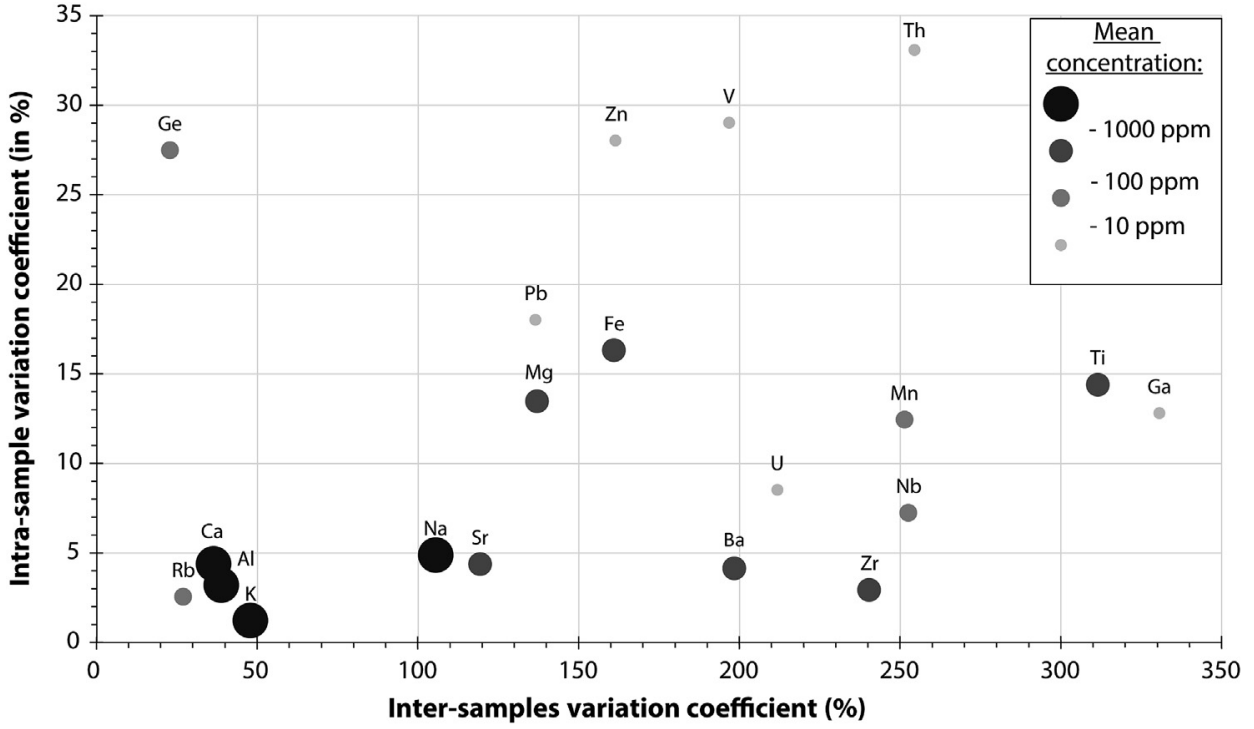

Fig. 2. Variations of minor and trace elements concentrations: intra-sample variation versus inter-sample variation. The intra-sample variation coefficient (y axis) is the mean of standard deviations (10) for all samples, expressed in percent. The inter-sample variation coefficient ( $x$ axis) is the standard deviation of the average compositions for all the samples, also expressed as a percentage. This plot shows that each sample is rather homogeneous (1-33\% variation on the $y$ axis) while concentrations vary more strongly from one sample to another (23-33\% variation along the $\mathrm{x}$ axis). Variations are more pronounced for low levels of concentration (light grey dots) while higher concentration elements ( $\mathrm{Na}, \mathrm{Ca}, \mathrm{Al}, \mathrm{K})$ show narrower ranges of variation. strontium respectively, compared to a range of $14.2-134.5 \mathrm{ppm}$ for the other samples).

In order to estimate inter-sample variations of trace element concentrations, we calculated the mean concentration of each element, the standard deviation (SD, 1 sigma) of this mean composition and expressed this SD in percent. Intra-sample variations were calculated as the mean of the SDs of each measured concentration, previously expressed in percent in order to make the calculation consistent. The inter-sample variation (x axis on Fig. 2) is rather high, from 25 to 350\%, which reveals a high chemical variability from one sample to another. By contrast, the intra-sample variation (y axis on Fig. 2) is much lower, from 1 to $33 \%$, which denotes a good internal homogeneity in impurity content for each sample. This trend is observed for all elements, whatever their mean concentration. Both variations are lower for the elements with concentrations above 1000 ppm (Al, Ca, K, Na, highlighted with larger, dark spots on Fig. 2).

Our data also show some clear relationships between some minor and/or trace elements (Fig. 3). The high trace element concentrations observed in samples WT92 and WT109 compared to the other samples, are clearly visible for $\mathrm{Ba}$ and $\mathrm{Sr}$, even compared to samples from the literature (shown in white on Fig. 3). Setting aside these two samples as exceptions, Ba is clearly correlated to $\mathrm{Sr}\left(\mathrm{R}^{2}=91 \%\right)$, and to a lesser extent to $\mathrm{K}\left(\mathrm{R}^{2}=39 \%\right)$ and $\mathrm{Ca}\left(\mathrm{R}^{2}=35 \%\right)$.

The sum of most abundant trivalent cations $\left(\mathrm{Al}^{3+}\right.$ and $\mathrm{Fe}^{3+}$ ) correlates well with the sum of most abundant divalent and monovalent cations $\left(\mathrm{Na}^{+}, \mathrm{Ba}^{+}, \mathrm{K}^{+}, \mathrm{Ca}^{2+}, \mathrm{Mg}^{2+}\right.$; Fig. 4). As suggested by Gaillou et al. (2008), the replacement of $\mathrm{Si}^{4+}$ by lower valence cations $\left(\mathrm{Al}^{3+}\right.$, $\mathrm{Fe}^{3+}$ ) induces a charge imbalance compensated for by the incorporation of monovalent and divalent cations between the tetrahedra in order to maintain electroneutrality. By comparison to opals from other deposits worldwide taken from the literature (Fig. 5), Wegel Tena opals are much richer in minor and trace elements that those from other deposits.

\subsection{REE pattern}

Rare Earth Elements concentrations were measured on 6 samples (Table 2). Contents were normalized to chondritic composition according to McDonough and Sun (1995). As shown in Fig. 6, three samples (WT109, WT92, WT134) display a REE pattern enriched in light REE (LREE) compared to heavy REE (HREE). The remaining 3 samples (WT159, WT86 and WT103) display the opposite behavior. A negative Ce anomaly is observed in WT103 and WT86, and a positive Eu anomaly in WT134.

\subsection{Oxygen isotope composition}

Table 3 presents the oxygen isotope composition of the 8 selected opal samples from Wegel Tena. We chose samples from 5 different mines (Koke Woha, Gelbate, Minch, Timkete Bahir, Nech Gedel) in order to check for variations within the whole study area. The $\delta^{18} \mathrm{O}$ values range from 26.52 to $30.98 \%$, with a mean value of $28.40 \pm 1.55 \%$. We also checked for variations within a single mine, by analyzing 3 samples from the Minch mine. The mean value for those 3 samples is $28.53 \pm 1.14 \%$. Hence, the variability between $\delta^{18} \mathrm{O}$ values of samples from a single mine is similar to that between samples from the whole study area.

\section{Discussion}

\subsection{Minor and trace elements}

\subsubsection{Electroneutrality in opal}

Gaillou et al. (2008) demonstrated a "pseudo-crystallochemistry" of opals by highlighting the linear correlation between the sum of trivalent cations substituting for the $\mathrm{Si}$ atoms $\left(\mathrm{Al}^{3+}\right.$ and $\mathrm{Fe}^{3+}$ ) and the sum of divalent and monovalent cations $\left(\mathrm{Na}^{+}, \mathrm{Ba}^{+}, \mathrm{K}^{+}, \mathrm{Ca}^{2+}, \mathrm{Mg}^{2+}\right)$. The replacement of $\mathrm{Si}^{4+}$ by cations of a lower valance induces a charge imbalance compensated for by the incorporation of other cations between tetrahedra in order to maintain electroneutrality. Previous geochemical measurements on Ethiopian opals from Mezezo (Gaillou et al., 2008) and Wegel Tena (Rondeau et al., 2012) revealed that most samples roughly follow this trend. Our data confirm the correlation between trivalent and divalent plus monovalent cations (Fig. 4), and hence this principle of electroneutrality. Our data also confirm that Wegel Tena opals are often much richer in trace elements than precious opals from any other deposits worldwide (Gaillou et al., 2008; Rondeau et al., 2012). We also note that the correlation coefficient between $(\mathrm{Al}+\mathrm{Fe})$ and $(\mathrm{Na}+\mathrm{Ba}+\mathrm{K}+\mathrm{Ca}+\mathrm{Mg})$ established at 0.75 by Gaillou et al. (2008) does not perfectly fit with our data, which are closer to a 1:1 trend (Fig. 4). Impurity-rich samples WT92 and WT109 also obey the electroneutrality principle, although they show atypical behaviors compared to the other samples (Figs. 3-5). When considering the comparison of the geochemical signature of all types of opal (opal-A and opal-CT, precious or common opal) from various geological contexts (volcanic or sedimentary host-rocks), we find that most opals follow this fairly good correlation (Fig. 5; data from Gaillou et al., 2008; Gallacher, 2001; McOrist and Smallwood, 1997; Rondeau et al., 2012). This may indicate that, whatever the geological context of opal 
a)

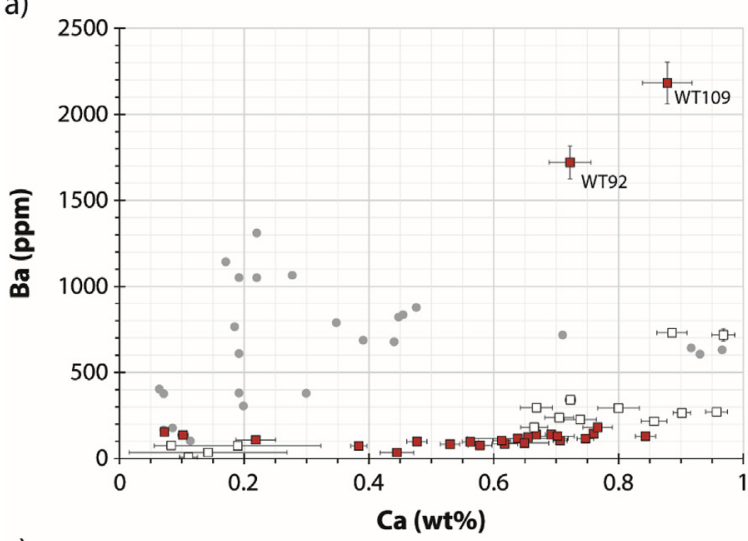

c)

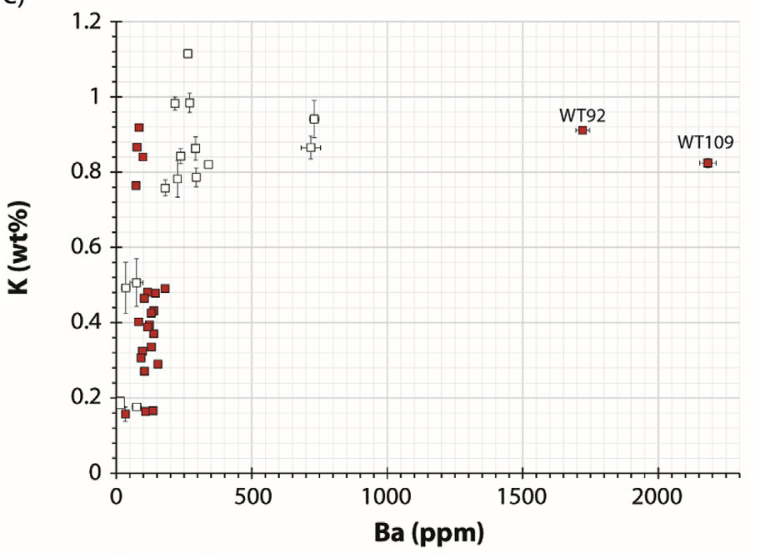

b)

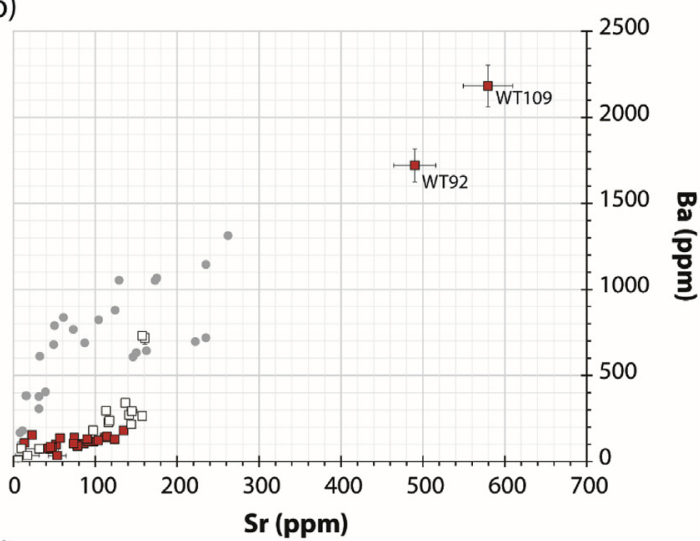

d)
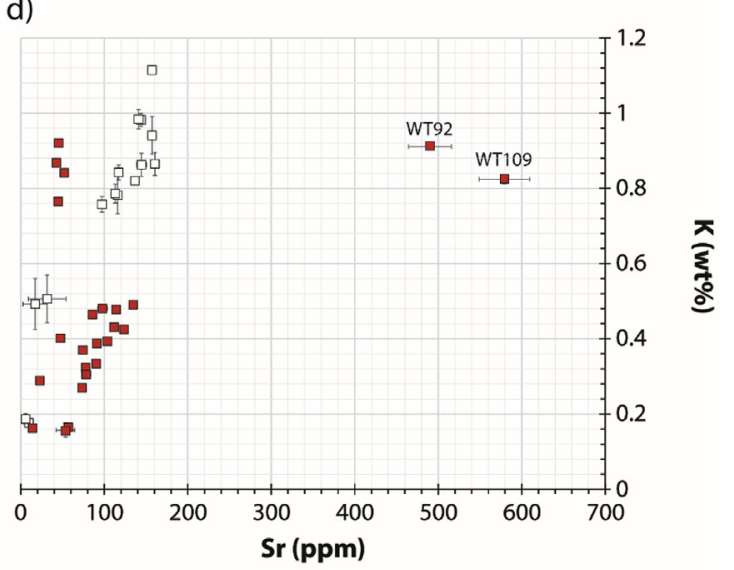

$\square$ Wegel Tena (this study) $\quad \square$ Tsehay Mewcha (Rondeau et al. 2012) • Bulk Rocks (Ayalew et al. 2002)

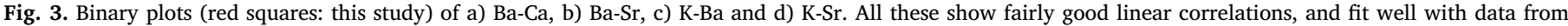

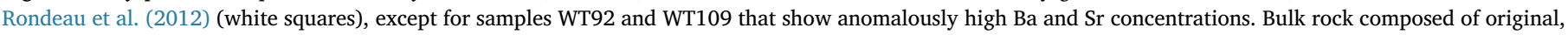

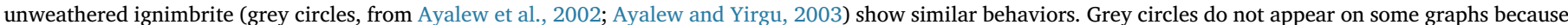

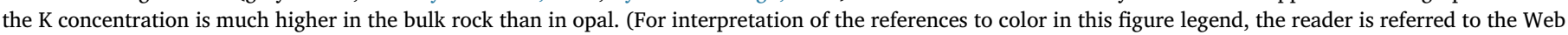
version of this article.)

formation and opal type, similar processes control trace element incorporation during opal precipitation. This suggests a chemical control, unexpected for an amorphous material, and thus merits further investigation in the future.

\subsubsection{Elemental correlation and silica sources}

In our samples, the good correlation between $\mathrm{Ba}, \mathrm{Sr}$, $\mathrm{Ca}$ and $\mathrm{K}$ (Fig. 3) indicates that these four elements may originate from a common source. Volcanic glass and alkali feldspar, the two main constituents of the host-rock, are likely the two primary sources for opal

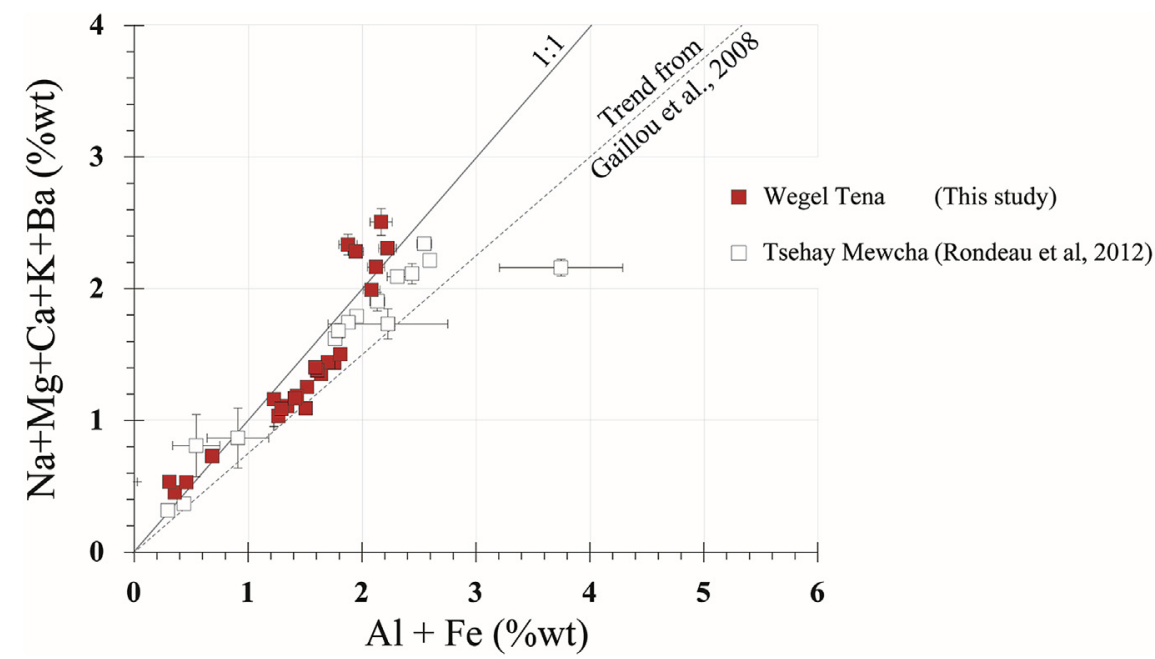

Fig. 4. Plots of the sum of trivalent cations content $\left(\mathrm{Al}^{3+}, \mathrm{Fe}^{3+}\right)$ versus the sum of mono-to divalent cations $\left(\mathrm{Na}+, \mathrm{Ca}^{2+}, \mathrm{Ba}^{2+}, \mathrm{K}^{+}, \mathrm{Mg}^{+}\right)$in the Ethiopian opals. The correlation is fairly good and close to a slope of 1:1. 


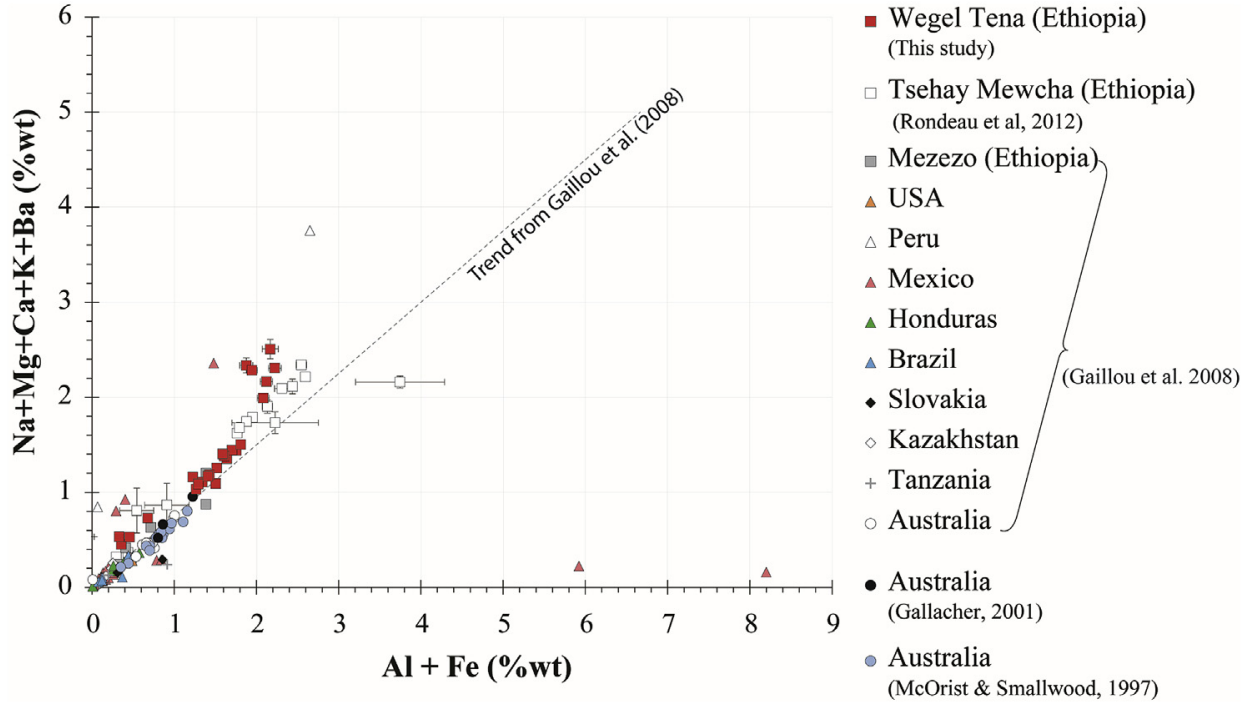

Fig. 5. Plots of the sum of trivalent cations $(\mathrm{Al} 3++\mathrm{Fe} 3+)$ versus the sum of mono- and divalent cations $(\mathrm{Na}++\mathrm{Ca} 2++\mathrm{Ba} 2++\mathrm{K}+$ $+\mathrm{Mg}+$ ) in opals. Each point corresponds to one sample. Values are available in the original publications. This highlights that the trend for most of the opals analyzed in the literature follows a correlation coefficient between 0.75 (as established by Gaillou et al., 2008) and 1. formation, consistent with the weathering sequence of ignimbrite (Gislason et al., 1996; White and Buss, 2013). In order to explain the large variability in the relative and absolute impurity concentrations among Wegel Tena opals, we can put forward several hypotheses. As proposed by Rondeau et al. (2012), silica released through weathering of the two above-mentioned sources barely mix in the geological system: each cavity where opal precipitates may record the geochemical signature of the local material that was weathered. Alternately, geochemical variations may be explained by different degrees of hostrock weathering: during weathering of silicate rocks, glass dissolves preferentially (Gislason et al., 1996; White and Buss, 2013), releasing abundant $\mathrm{Si}$ and $\mathrm{Al}$. Later, feldspar weathering releases silica, aluminum and alkali oxides $\left(\mathrm{Al}_{2} \mathrm{O}_{3}, \mathrm{~K}_{2} \mathrm{O}\right.$ and $\left.\mathrm{NaO}\right)$ and their typical substituting elements (Eu, Ba and Sr, Icenhower and London, 1996; Morse and Allaz, 2013). Therefore, we suggest that opals with a higher Ba, Eu and $\mathrm{Sr}$ content may originate from more intense weathering, and subsequently from more intense feldspar dissolution, than the other samples. These two processes may occur concomitantly. Alternately and/or additionally, opal composition may be affected by the presence of nanoinclusions enriched in other impurities (Ba, Sr, Eu ...).

The relative enrichment in minor and trace elements of many Ethiopian opals compared to opals from other deposits may be explained by the relative proximity of their silica source, likely glass (and to a lesser extent feldspar) in ignimbrites. By contrast, in the case of the
Australian deposits, the source of silica is several dozen (or hundreds) of meters above the opal-rich layer (Rey, 2013). When groundwater percolates through substantial depths, secondary minerals, such as iron oxy-hydroxides, can crystallize and incorporate elements other than $\mathrm{Si}$, decreasing the impurity concentration in the opal. Mexican opals are also hosted within rhyolitic ignimbrites, but they formed from the hydrothermal alteration of the host-ignimbrite, and at higher temperature (Spencer et al., 1992) than the Ethiopian opals. Mexican opals are often associated with hematite and iron oxy-hydroxides that may also incorporate trace elements (Gübelin, 1986; Spencer et al., 1992), and subsequently explain lower concentrations of trace elements when compared to Ethiopian opals.

\subsection{Rare earth elements patterns}

Although REE are extensively used to trace geological processes (e.g. hydrothermal alteration and weathering; Bau, 1991; Compton et al., 2003; Laveuf and Cornu, 2009; Ma et al., 2011; Nesbitt, 1979), REE abundances in opals have rarely been measured. Wegel Tena opals analyzed in this study, as well as those analyzed by Rondeau et al. (2012), show REE abundances normalized to chondrite in the range identified by Gaillou et al. (2008), from 0.01 to 100 . Rondeau et al. (2012) observed nearly flat normalized REE patterns, with occasional $\mathrm{Ce}$ and Eu negative anomalies. Gaillou et al. (2008) observed similar

Table 2

Concentration of Rare Earth Elements (REE) in Wegel Tena opals (n.d. = not detected).

\begin{tabular}{|c|c|c|c|c|c|c|c|c|c|c|c|c|}
\hline \multirow[t]{2}{*}{ Element (ppm) } & \multicolumn{2}{|l|}{ WT86 } & \multicolumn{2}{|l|}{ WT92 } & \multicolumn{2}{|c|}{ WT103 } & \multicolumn{2}{|c|}{ WT109 } & \multicolumn{2}{|c|}{ WT134 } & \multicolumn{2}{|l|}{ WT159 } \\
\hline & Mean & $1 \sigma$ & Mean & $1 \sigma$ & Mean & $1 \sigma$ & Mean & $1 \sigma$ & Mean & $1 \sigma$ & Mean & $1 \sigma$ \\
\hline Sc & 0.51 & 0.17 & 8.58 & 1.35 & 0.51 & 0.19 & 4.68 & 1.22 & 0.61 & 0.22 & 13.38 & 1.37 \\
\hline $\mathbf{Y}$ & 0.09 & 0.01 & 9.27 & 0.59 & 2.74 & 0.10 & 20.46 & 1.19 & 0.30 & 0.02 & 14.29 & 0.88 \\
\hline La & 0.01 & 0.0028 & 8.31 & 0.51 & 0.16 & 0.011 & 23.03 & 1.31 & 0.17 & 0.011 & 0.32 & 0.05 \\
\hline $\mathrm{Ce}$ & 0.01 & 0.0037 & 21.20 & 1.16 & 0.09 & 0.009 & 48.62 & 2.56 & 0.44 & 0.022 & 0.98 & 0.10 \\
\hline Pr & 0.01 & 0.0021 & 2.34 & 0.16 & 0.03 & 0.004 & 5.21 & 0.32 & 0.05 & 0.006 & 0.13 & 0.03 \\
\hline Nd & n.d. & & 8.58 & 0.71 & 0.15 & 0.033 & 22.06 & 1.46 & 0.19 & 0.042 & 0.32 & 0.11 \\
\hline $\mathrm{Sm}$ & 0.03 & 0.018 & 1.94 & 0.30 & 0.06 & 0.021 & 5.43 & 0.54 & 0.06 & 0.024 & 0.20 & 0.09 \\
\hline $\mathbf{E u}$ & n.d. & & 0.47 & 0.08 & 0.02 & 0.007 & 1.48 & 0.15 & 0.04 & 0.010 & 0.09 & 0.03 \\
\hline Gd & 0.02 & 0.013 & 1.57 & 0.25 & 0.14 & 0.028 & 4.31 & 0.45 & 0.06 & 0.021 & 0.26 & 0.11 \\
\hline $\mathrm{Tb}$ & 0.00 & 0.002 & 0.28 & 0.04 & 0.03 & 0.005 & 0.77 & 0.08 & 0.01 & 0.004 & 0.11 & 0.03 \\
\hline Dy & 0.02 & 0.015 & 1.72 & 0.22 & 0.26 & 0.032 & 5.16 & 0.43 & 0.06 & 0.018 & 0.81 & 0.15 \\
\hline Ho & 0.00 & 0.002 & 0.32 & 0.05 & 0.07 & 0.008 & 0.98 & 0.09 & 0.01 & 0.004 & 0.25 & 0.04 \\
\hline Er & 0.02 & 0.010 & 0.90 & 0.13 & 0.23 & 0.029 & 2.76 & 0.25 & 0.04 & 0.014 & 1.30 & 0.17 \\
\hline $\mathrm{Tm}$ & 0.01 & 0.003 & 0.14 & 0.03 & 0.04 & 0.005 & 0.38 & 0.05 & 0.01 & 0.003 & 0.40 & 0.05 \\
\hline Yb & 0.03 & 0.016 & 1.03 & 0.17 & 0.28 & 0.042 & 2.50 & 0.28 & 0.05 & 0.018 & 5.22 & 0.49 \\
\hline Lu & 0.01 & 0.003 & 0.16 & 0.03 & 0.04 & 0.006 & 0.30 & 0.04 & 0.01 & 0.003 & 1.16 & 0.11 \\
\hline
\end{tabular}



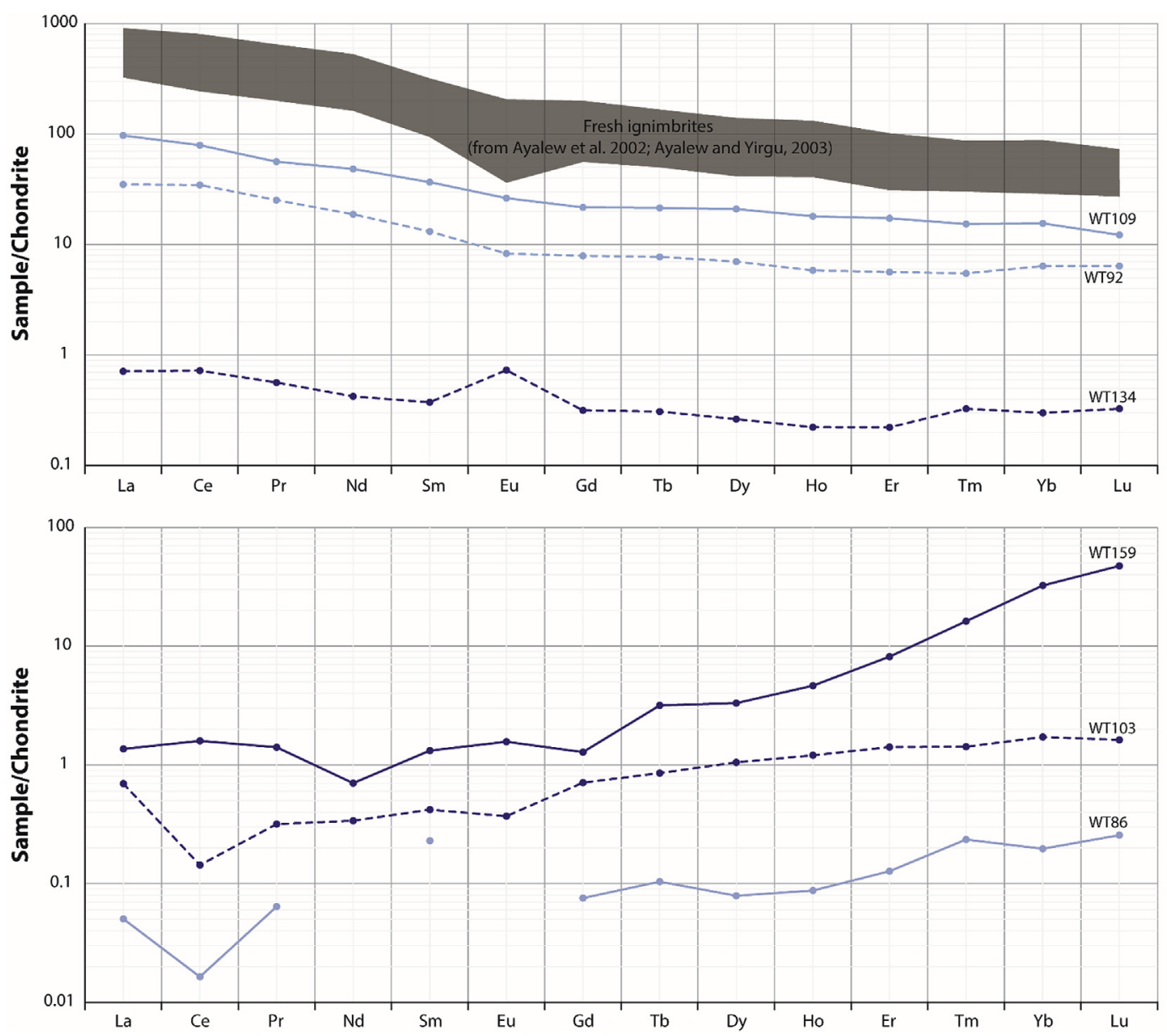

Fig. 6. REE patterns of the studied opals. The grey field is the range of REE patterns for fresh whole-rocks (Ayalew et al., 2002; Ayalew and Yirgu, 2003). The REE distribution of opals may be divided into 2 groups: one group with a HREE content higher than LREE, and one group showing the opposite behavior. We observe Eu and $\mathrm{Ce}$ anomalies for some of the samples.

Table 3

Oxygen isotope compositions of the opal samples from Wegel Tena area.

\begin{tabular}{llll}
\hline Samples & Mine & $\begin{array}{l}\text { Number of } \\
\text { analyses }\end{array}$ & $\begin{array}{l}\delta^{18} \text { O (\%o vs VSMOW)Mean and } \\
\text { standard deviation }\end{array}$ \\
\hline WT92 & Koke Woha & 1 & 28.13 \\
WT107 & Gelbate & 2 & $30.98 \pm 0.03$ \\
WT134 & Minch & 1 & 28.1 \\
WT149 & & 1 & 27.68 \\
WT150 & & 2 & $29.83 \pm 0.18$ \\
WT171 & Timkete Bahir & 2 & $26.65 \pm 0.43$ \\
WT176 & & 1 & 26.52 \\
WT208 & Nech Gedel & 2 & $29.33 \pm 0.46$ \\
Boulangé & Standards & 4 & $16.28 \pm 0.28$ \\
2008 & & & \\
NBS28 & & 1 & 9.72 \\
MGS60 & & 2 & $36.51 \pm 0.44$
\end{tabular}

normalized REE patterns in opals and their host rocks. By contrast, normalized REE patterns of opals analyzed here display strong variations, and only two samples (WT92 and WT109) out of six show a pattern similar to that of the host rock (grey area on Fig. 6; Ayalew et al., 2002). The relationships between the REE signatures of the hostrocks and opals at Wegel Tena are not as clear as in other deposits (Gaillou et al., 2008). This is consistent with the hypothesis advanced in the previous section (elemental correlations and silica sources): the fluids likely did not percolate to great depth through the weathering rock, and hence fluids with different silica sources did not have time or space to mix. Thus, each opal reflects the composition and degree of weathering of the source rock in its immediate vicinity.

\subsubsection{Ce anomaly}

Samples WT103 and WT86 exhibit a negative Ce anomaly. The origin of $\mathrm{Ce}$ anomalies have been intensely studied over recent decades, because its behavior differs from neighboring REE (Bau et al., 1996; Braun et al., 1990; Hein et al., 1997; Seto and Akagi, 2008; Tanaka et al., 2010). Cerium may exist in two ionization states: $\mathrm{Ce}^{3+}$ and $\mathrm{Ce}^{4+}$. Depletion in Ce is explained by a variation in redox conditions, either due to the formation of $\mathrm{CeO}_{2}$ (Braun et al., 1990; Hein et al., 1978), or due to preferential desorption of trivalent REE compared to $\mathrm{Ce}^{4+}$ from iron and manganese oxy-hydroxides (Bau, 1999; Leybourne et al., 2000; Pédrot et al., 2015). Microbial mediation is also inferred to explain Ce anomalies (Moffett, 1990; Tanaka et al., 2010). In the present case, the wide range of observed Ce anomalies likely result from the wide range of redox conditions experienced during the weathering/pedogenetic processes leading to opal formation. Again, this underlines the contrasting local conditions of opal formation from one sample to another.

\subsubsection{Eu anomaly}

The positive Eu anomaly observed in opal WT134 (Fig. 6) could originate from several sources and processes. $\mathrm{Ce}$, and Eu anomalies may also be related to $\mathrm{Fe}$ and $\mathrm{Mn}$ oxyhydroxides in specific redox conditions. However, this requires strongly reducing conditions that are rarely encountered (Laveuf and Cornu, 2009; Panahi et al., 2000). Positive Eu anomalies are commonly related to calcic feldspars, where $\mathrm{Ca}^{2+}$ is substituted by $\mathrm{Eu}^{2+}$ (Condie et al., 1995; Laveuf and Cornu, 2009; 
Nagasawa, 1971; Panahi et al., 2000). Fresh ignimbrites from Wegel Tena exhibit a negative Eu anomaly, due to feldspar fractionation that is well-known in magmatic differentiation (Ayalew and Yirgu, 2003; Ayalew et al., 2002). The rare Eu-rich samples may reflect weathering conditions near rare calcic feldspars, while other samples not enriched in Eu reflect the composition of the mean host-rock. Eu-rich samples are also rich in Sr, which supports the hypothesis of a composition derived from feldspar weathering, as both calcic and alkali feldspars are commonly enriched in Sr (Heier, 1962; Nagasawa, 1971; Weill and Drake, 1973).

\subsection{Oxygen isotope composition}

The Wegel Tena $\delta^{18} \mathrm{O}_{\text {opal }}$ signatures (from 26.52 to $30.98 \%$; Table 3 ) are consistent with the $\delta^{18} \mathrm{O}$ data previously obtained for opals of the same provenance (from 26.17 to $27.36 \%$; Vysotskiy et al., 2013). Such high $\delta^{18} \mathrm{O}$ values were previously interpreted as low-temperature signatures (Henderson et al., 1971; Murata et al., 1977; Pisciotto, 1981). However, the $\delta^{18} \mathrm{O}$ of a mineral depends on both the $\delta^{18} \mathrm{O}$ of the forming water $\left(\delta^{18} \mathrm{O}_{\text {forming water }}\right)$ and the formation temperature. Several silica-water fractionation equations have been determined experimentally (e.g. Dodd and Sharp, 2010; Sharp et al., 2016 and references therein), leading to values of isotope fractionation factors that can differ by several \%o. Hereafter, the most recent silica-water fractionation equation calculated from the compilation of previous studies for low and high temperatures will be used (Sharp et al., 2016). Considering the isotopic composition of the modern meteoric water (close to $0 \%$; IAEA/WMO, 2017) and the current mean annual temperature, an opal formed in isotopic equilibrium with modern meteoric water would have a $\delta^{18} \mathrm{O}=39 \%$. The measured $\delta^{18} \mathrm{O}_{\text {opal }}$ values are thus lower by $8-13 \%$. Two main parameters may explain this difference: a

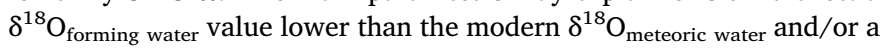
temperature of formation higher than the current mean annual atmospheric temperature. These two factors are assessed below.

\subsection{1. $\delta^{18} O_{\text {forming water }}$ lower than modern $\delta^{18} O_{\text {meteoric water }}$ ?}

Assuming that the Oligocene Wegel Tena opals formed from a pedogenic phase implies that the formation water was an Oligocene soil water. Soil water is largely fed by meteoric water and the $\delta^{18} \mathrm{O}_{\text {meteoric }}$ water depends on the $\delta^{18} \mathrm{O}$ composition of the oceanic source, the transport pathway followed by the air masses, and the amount of precipitation (Dansgaard, 1964; Gat, 1996). A $\delta^{18} \mathrm{O}$ value of the oceanic source significantly lower than the modern one (i.e. by more than 1\%o) cannot be invoked for the Oligocene, a period of rapid expansion of large continental ice sheets leading to values in the oceanic $\delta^{18} \mathrm{O}$ close to the modern one (Galeotti et al., 2016; Zachos et al., 1996). On the contrary, moisture sources different from the modern ones may have played a role. Today, the source of moisture changes seasonally, switching from the Atlantic/Congo area $\left({ }^{18} \mathrm{O}\right.$-enriched air mass) to the Indian Ocean area $\left({ }^{18} \mathrm{O}\right.$-depleted air mass) over the year and decreasing the $\delta^{18} \mathrm{O}_{\text {meteoric water }}$ by $3-4 \%$ (Kebede and Travi, 2012). In addition, during the Oligocene, the climate was wetter and warmer than at present, as attested to by the presence of tropical forest species recorded by paleobotanical and paleoecological data from Chilga, $150 \mathrm{~km}$ east of Wegel Tena (Currano et al., 2010; García Massini et al., 2011; Jacobs et al., 2005; Massini et al., 2010), which may have led to higher precipitation and lower $\delta^{18} \mathrm{O}_{\text {meteoric water values (due to a higher "amount }}$ effect" from Dansgaard, 1964). Differences in moisture sources and in the amount effect have previously been suggested to explain lower $\delta^{18} \mathrm{O}_{\text {meteoric water }}$ during the wet Pliocene period and wet phases of the

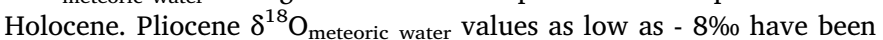
reconstructed from isotope analyses of mollusk shells, pedogenetic carbonates, and fossil teeth from of the Ethiopian plateau (Hailemichael

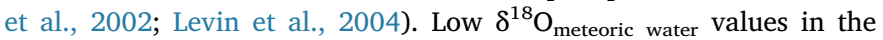
Holocene have been inferred to result from a groundwater $\delta^{18} \mathrm{O}$ on the plateau which was lower than - 4.5\%o (Kebede and Travi, 2012). The
Oligocene period was tectonically active in East Africa, due to the Afar uplift, and rifting (Ayalew and Yamagishi, 2004; Hofmann et al., 1997; McDougall et al., 1975; Pik et al., 2003). However, the mean elevation of the highlands was close to the modern one (Pik et al., 2003) and the altitude effect $(-0.1 \% 0 / 100 \mathrm{~m}$; Kebede and Travi, 2012) cannot be

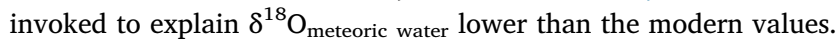

After being fed by meteoric waters, soil water can be subject to evaporation leading to ${ }^{18} \mathrm{O}$-enrichment of several \%o in the first few decimeters (e.g., Gaj et al., 2016; Liu et al., 2010). As Wegel Tena opals occur several meters below the paleosurface, they probably precipitated from soil water which was not significantly affected by evaporative fractionation. The soil water may have been fed by precipitation whose total amount and relative contribution of moisture sources were different from that of contemporary precipitation.

\subsubsection{Forming temperature higher than the current mean annual atmospheric temperature?}

In the model proposed by Chauviré et al. (2017b), it was proposed that opal precipitation may be triggered by the confinement of the water-rich weathered layers due to the emplacement of new ignimbrite layers above the soil. The surface temperature would rise due to the deposition of hot ignimbrite layers and may heat the fluids circulating in the underlying, weathered layers. Using the thermal diffusion coefficient for rhyolite rocks, it is estimated that the temperature can reach several hundreds of degrees up to tens of meters deep, for decades (Manley, 1992). According to the Sharp et al. (2016) fractionation equation, and given the $\delta^{18} \mathrm{O}$ signatures of the Wegel Tena opals, a formation temperature of $100-200{ }^{\circ} \mathrm{C}$ would require a $\delta^{18} \mathrm{O}_{\text {forming water }}$ ranging from 5.2 to $19.3 \%$ (Hypothesis 1 on Fig. 7). Such high $\delta^{18} \mathrm{O}$ values result from surface water evaporation: $\delta^{18} \mathrm{O}$ values as high as $8 \%$ were measured in modern lakes subjected to high evaporation on the Ethiopian plateau (Hailemichael et al., 2002). Thus, the Wegel Tena opal isotopic composition could be explained by assuming a water significantly enriched in ${ }^{18} \mathrm{O}$ by surficial evaporation and subsequently heated by ignimbrite deposition. However, opal-host rocks do not show any petrological or mineralogical evidence of high-temperature alteration. On the contrary, Chauviré et al. (2017b) observed that opalbearing rocks still contain glass shards and mafic minerals (e.g. clinopyroxene) that would have been altered during high temperature weathering (Keith et al., 1978; Keith and Muffler, 1978; Matyskiela, 1997). Moreover, the consistency of the $\delta^{18} \mathrm{O}_{\text {opal }}$ signatures within the entire studied area suggests no significant difference in the temperature of formation, which is not in agreement with the large heterogeneity of temperatures reconstructed by Ayalew et al. (2002) for the formation of ignimbrites on the Wegel Tena plateau. Therefore, the hypothesis that opal formed at $100-200{ }^{\circ} \mathrm{C}$ during overlying hot ignimbrite deposition is not supported by the petrographic observations.

Assuming an Oligocene $\delta^{18} \mathrm{O}_{\text {forming water similar to the modern }}$ $\delta^{18} \mathrm{O}_{\text {meteoric water, }}$ the measured $\delta^{18} \mathrm{O}_{\text {opal }}$ would imply an Oligocene soil temperature higher than $46{ }^{\circ} \mathrm{C}$ (Hypothesis 2 on Fig. 7), which is unrealistic. However, assuming an Oligocene temperature higher than at present by only $2-5{ }^{\circ} \mathrm{C}$ (i.e. $18-21^{\circ} \mathrm{C}$ ) would imply a $\delta^{18} \mathrm{O}_{\text {forming water }}$ ranging from -11.2 to $-6.5 \%$ o (Hypothesis 3 on Fig. 7). This range

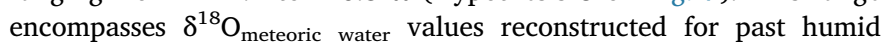
periods, as discussed above. Hypothesis 3 is thus the most realistic: it is consistent with precipitation of opals in soils under an Oligocene climate warmer and wetter than today, in agreement with previous paleoclimate assumptions (Abbate et al., 2014; Currano et al., 2011; Jacobs et al., 2005), and with precipitation fed by moisture sources which differ from the present ones.

\section{Conclusion}

The elemental composition of Wegel Tena opals suggests that they precipitated from silica-rich waters fed by the weathering of ignimbrite, specifically the weathering of glass and feldspar. As opals in the Wegel 

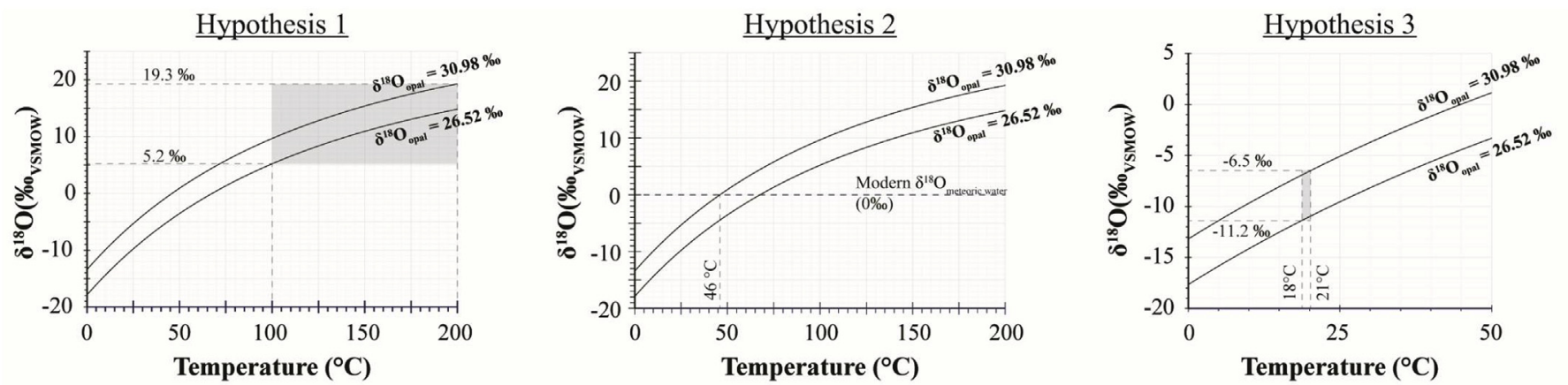

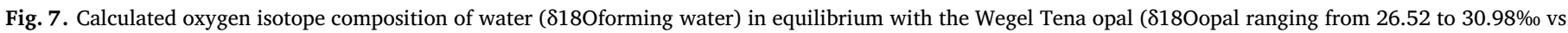

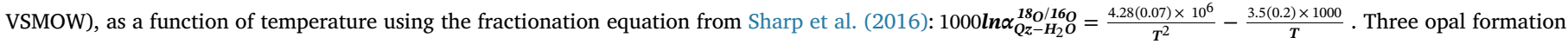

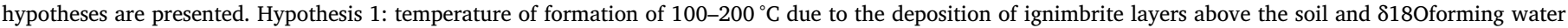

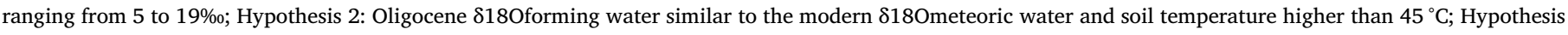

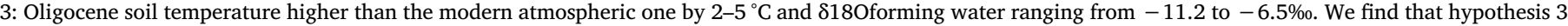
is the most reasonable (see text for details).

Tena area have been found in lenses throughout the weathered ignimbritic layers, the assumption was made that similar weathering conditions may have prevailed during their formation (Chauviré et al., 2017b; Rondeau et al., 2012). The REE pattern and anomalies confirm that the genesis of the Wegel Tena opals occurred during weathering processes, however they also suggest that a wide range of physical and chemical conditions prevailed, either at the regional (Wegel Tena plateau), local (within the same mine) or intra-sample scales. We propose that opal composition is strongly dependent on the very local environment, because of the strong confinement effect of the cavity where opal precipitates. In addition, opal composition is also determined by the degree of weathering and the composition of source materials. This study highlights how trace elements (including REE) can give key insights into the processes contributing to the formation of opal. The oxygen isotope data allow us to propose several hypotheses for the conditions of opal genesis at this site. The most robust hypothesis, consistent with our observations is that the opals have a pedogenic origin at ambient temperature $\left(18-21^{\circ} \mathrm{C}\right)$ involving a weakly evaporated soil water fed by meteoric water with $\delta^{18} \mathrm{O}$ value lower than the modern value, during an Oligocene period warmer and wetter than today.

\section{Acknowledgments}

We are thankful for the help of Jessica Langlade (from Ifremer, Brest) for the EPMA measurement and of Nicolas Stephant (Institut des Matériaux Jean Rouxel, Nantes) for EDS analyses. Opal sections were efficiently prepared by Laurent Lenta (Laboratoire de Planétologie et Géodynamique). Jean-Pierre Lorand (Laboratoire de Planétologie et Géodynamique) was very helpful for interpretation of geochemical features. We also thank Corinne Sonzogni and Martine Couapel (CEREGE, Aix-en-provence) for the isotopic measurements. Author are also thankful for the help of Susan Conway.

\section{Appendix A. Supplementary data}

Supplementary data to this article can be found online at https:// doi.org/10.1016/j.apgeochem.2018.12.028.

\section{References}

Abbate, E., Bruni, P., Ferretti, M.P., Delmer, C., Laurenzi, M.A., Hagos, M., Bedri, O., Rook, L., Sagri, M., Libsekal, Y., Peter, M., Ada, M., 2014. The East Africa Oligocene intertrappean beds: Regional distribution, depositional environments and Afro/ Arabian mammal dispersals. J. Afr. Earth Sci. 99, 1-27. https://doi.org/10.1016/j. jafrearsci.2013.11.001.

Alexandre, A., Basile-Doelsch, I., Sonzogni, C., Sylvestre, F., Parron, C., Meunier, J.-D.
Colin, F., 2006. Oxygen isotope analyses of fine silica grains using laser-extraction technique: Comparison with oxygen isotope data obtained from ion microprobe analyses and application to quartzite and silcrete cement investigation. Geochem. Cosmochim. Acta 70, 2827-2835. https://doi.org/10.1016/j.gca.2006.03.003.

Alexandre, A., Bouvet, M., Abbadie, L., 2011. The role of savannas in the terrestrial Si cycle: A case-study from Lamto, Ivory Coast. Global Planet. Change 78, 162-169.

Alexandre, A., Meunier, J.-D., Colin, F., Koud, J.-M., 1997. Plant impact on the biogeochemical cycle of silicon and related weathering processes. Geochem. Cosmochim. Acta 61, 677-682. https://doi.org/10.1016/S0016-7037(97)00001-X.

Arnórsson, S., 1985. The use of mixing models and chemical geothermometers for estimating underground temperatures in geothermal systems. J. Volcanol. Geoth. Res. 23, 299-335. https://doi.org/10.1016/0377-0273(85)90039-3.

Ayalew, D., Barbey, P., Marty, B., Reisberg, L., Yirgu, G., Pik, R., 2002. Source, genesis, and timing of giant ignimbrite deposits associated with Ethiopian continental flood basalts. Geochem. Cosmochim. Acta 66, 1429-1448. https://doi.org/10.1016/ S0016-7037(01)00834-1.

Ayalew, D., Yirgu, G., 2003. Crustal contribution to the genesis of Ethiopian plateau rhyolitic ignimbrites: basalt and rhyolite geochemical provinciality. J. Geol. Soc. London. 160, 47-56. https://doi.org/10.1144/0016-764901-169.

Ayalew, L., Yamagishi, H., 2004. Slope failures in the Blue Nile basin, as seen from landscape evolution perspective. Geomorphology 57, 95-116. https://doi.org/10. 1016/S0169-555X(03)00085-0.

Baker, J., Snee, L., Menzies, M., 1996. A brief Oligocene period of flood volcanism in Yemen: implications for the duration and rate of continental flood volcanism at the Afro-Arabian triple junction. Earth Planet. Sci. Lett. 138, 39-55. https://doi.org/10. 1016/0012-821X(95)00229-6.

Barnes, J.D., Paulick, H., Sharp, Z.D., Bach, W., Beaudoin, G., 2009. Stable isotope $\left(\delta^{18} \mathrm{O}\right.$, $\delta \mathrm{D}, \delta^{37} \mathrm{Cl}$ ) evidence for multiple fluid histories in mid-Atlantic abyssal peridotites (ODP Leg 209). Lithos 110, 83-94. https://doi.org/10.1016/j.lithos.2008.12.004.

Bartoli, F., Bittencourt-Rosa, D., Doirisse, M., Meyer, R., Philippy, R., Samama, J.-C., 1990. Role of aluminium in the structure of Brazilian opals. Eur. J. Mineral. 2, 611-620. https://doi.org/10.1127/ejm/2/5/0611.

Bau, M., 1999. Scavenging of dissolved yttrium and rare earths by precipitating iron oxyhydroxide: Experimental evidence for Ce oxidation, Y-Ho fractionation, and lanthanide tetrad effect. Geochem. Cosmochim. Acta 63, 67-77. https://doi.org/10. 1016/S0016-7037(99)00014-9.

Bau, M., 1991. Rare-Earth Element Mobility During Hydrothermal and Metamorphic Fluid Rock Interaction and the Significance of the Oxidation-State of Europium. Chem. Geol. 93, 219-230. https://doi.org/10.1016/0009-2541(91)90115-8.

Bau, M., Koschinsky, A., Dulski, P., Hein, J.R., 1996. Comparison of the partitioning behaviours of yttrium, rare earth elements, and titanium between hydrogenetic marine ferromanganese crusts and seawater. Geochem. Cosmochim. Acta 60, 1709-1725. https://doi.org/10.1016/0016-7037(96)00063-4.

Bayliss, P., Males, P.A., 1965. The Mineralogical Similarity of Precious and Common Opal from Australia. Mineral. Mag. 35, 429-431. https://doi.org/10.1180/minmag.1965. 035.270.22.

Botz, R., Bohrmann, G., 1991. Low-temperature opal-CT precipitation in Antarctic deepsea sediments: evidence from oxygen isotopes. Earth Planet. Sci. Lett. 107, 612-617. https://doi.org/10.1016/0012-821X(91)90105-Q.

Braun, J.J., Pagel, M., Muller, J.P., Bilong, P., Michard, A., Guillet, B., 1990. Cerium anomalies in lateritic profiles. Geochem. Cosmochim. Acta 54, 781-795. https://doi. org/10.1016/0016-7037(90)90373-S.

Brown, L.D., Ray, A.S., Thomas, P.S., 2004. Elemental analysis of Australian amorphous banded opals by laser-ablation ICP-MS. Neues Jahrbuch Mineral. Monatsh. 2004, 411-424. https://doi.org/10.1127/0028-3649/2004/2004-0411.

Buerger, M.J., Shoemaker, G.L., 1972. Thermal Effect in Opal Below Room Temperature. Proc. Natl. Acad. Sci. Unit. States Am. 69, 3225-3227. https://doi.org/10.1073/pnas. 69.11.3225.

Campbell, K.A., Guido, D.M., Gautret, P., Foucher, F., Ramboz, C., Westall, F., 2015. Geyserite in hot-spring siliceous sinter: Window on Earth's hottest terrestrial (paleo) 
environment and its extreme life. Earth Sci. Rev. 148, 44-64. https://doi.org/10. 1016/j.earscirev.2015.05.009.

Channing, A., Butler, I.B., 2007. Cryogenic opal-A deposition from Yellowstone hot springs. Earth Planet. Sci. Lett. 257, 121-131. https://doi.org/10.1016/j.epsl.2007. 02.026 .

Chapligin, B., Leng, M.J., Webb, E., Alexandre, A., Dodd, J.P., Ijiri, A., Lücke, A., Shemesh, A., Abelmann, A., Herzschuh, U., Longstaffe, F.J., Meyer, H., Moschen, R., Okazaki, Y., Rees, N.H., Sharp, Z.D., Sloane, H.J., Sonzogni, C., Swann, G.E.A., Sylvestre, F., Tyler, J.J., Yam, R., 2011. Inter-laboratory comparison of oxygen isotope compositions from biogenic silica. Geochim. Cosmochim. Acta 75, 7242-7256. https://doi.org/10.1016/j.gca.2011.08.011.

Chapligin, B., Meyer, H., Friedrichsen, H., Marent, A., Sohns, E., Hubberten, H.-W., 2010. A high-performance, safer and semi-automated approach for the $\delta^{18} \mathrm{O}$ analysis of diatom silica and new methods for removing exchangeable oxygen. Rapid Commun. Mass Spectrom. 24, 2655-2664. https://doi.org/10.1002/rcm.4689.

Chauviré, B., Rondeau, B., Mangold, N., 2017a. Near infrared signature of opal and chalcedony as a proxy for their structure and formation conditions. Eur. J. Mineral. 29, 409-421. https://doi.org/10.1127/ejm/2017/0029-2614.

Chauviré, B., Rondeau, B., Mazzero, F., Ayalew, D., 2017b. The Precious Opal Deposit At Wegel Tena, Ethiopia: Formation Via Successive Pedogenesis Events. Can. Mineral. 55, 701-723. https://doi.org/10.3749/canmin.1700010.

Compton, J.S., White, R.A., Smith, M., 2003. Rare earth element behavior in soils and salt pan sediments of a semi-arid granitic terrain in the Western Cape, South Africa. Chem. Geol. 201, 239-255. https://doi.org/10.1016/S0009-2541(03)00239-0.

Condie, K.C., Dengate, J., Cullers, R.L., 1995. Behavior of rare earth elements in a paleoweathering profile on granodiorite in the Front Range, Colorado, USA. Geochem. Cosmochim. Acta 59, 279-294. https://doi.org/10.1016/0016-7037(94)00280-Y.

Conley, D.J., 2002. Terrestrial ecosystems and the global biogeochemical silica cycle. Global Biogeochem. Cycles 16, 1-8. https://doi.org/10.1029/2002GB001894.

Coulié, E., Quidelleur, X., Gillot, P.-Y., Courtillot, V., Lefèvre, J.-C., Chiesa, S., 2003. Comparative $\mathrm{K}-\mathrm{Ar}$ and $\mathrm{Ar} / \mathrm{Ar}$ dating of Ethiopian and Yemenite Oligocene volcanism: implications for timing and duration of the Ethiopian traps. Earth Planet. Sci. Lett. 206, 477-492. https://doi.org/10.1016/S0012-821X(02)01089-0.

Crespin, J., Alexandre, A., Sylvestre, F., Sonzogni, C., Paillès, C., Garreta, V., 2008. IR laser extractiontechnique applied to oxygen isotope analysis of small biogenic silica samples. Anal. Chem. 80, 2372-2378. https://doi.org/10.1021/ac071475c.

Currano, E.D., Jacobs, B.F., Pan, A.D., Tabor, N.J., 2011. Inferring ecological disturbance in the fossil record: A case study from the late Oligocene of Ethiopia. Palaeogeogr. Palaeoclimatol. Palaeoecol. 309, 242-252. https://doi.org/10.1016/j.palaeo.2011. 06.007.

Currano, E.D., Jacobs, B.F., Tabor, N., Pan, A.D., 2010. Reconstruction paleolandscape, apeloclimate, and paleoecology of the late Oligocene Chigla Basin, Northwestern Ethiopia. In: Tectonic Crossroads: Evolving Orogens of Eurasia-Africa-Arabia.

Dansgaard, W., 1964. Stable isotopes in precipitation. Tellus 16, 436-468. https://doi. org/10.1111/j.2153-3490.1964.tb00181.x.

DeMaster, D.J., 2014. The diagenesis of biogenic silica: chemical transformations oc curring in the water column, seabed, and crust. In: Treatise on Geochemistry. Elsevier, pp. 103-111. https://doi.org/10.1016/B978-0-08-095975-7.00704-X.

Dodd, J.P., Sharp, Z.D., 2010. A laser fluorination method for oxygen isotope analysis of biogenic silica and a new oxygen isotope calibration of modern diatoms in freshwater environments. Geochem. Cosmochim. Acta 74, 1381-1390. https://doi.org/10.1016/ j.gca.2009.11.023.

Dutkiewicz, A., Landgrebe, T.C.W., Rey, P.F., 2015. Origin of silica and fingerprinting of Australian sedimentary opals. Gondwana Res. 27, 786-795. https://doi.org/10. 1016/j.gr.2013.10.013.

Fraysse, F., Pokrovsky, O.S., Schott, J., Meunier, J.D., 2009. Surface chemistry and reactivity of plant phytoliths in aqueous solutions. Chem. Geol. 258, 197-206. https:// doi.org/10.1016/j.chemgeo.2008.10.003.

Fritsch, E., Ostrooumov, M., Rondeau, B., Barreau, A., Albertini, D., Marie, A.-M., Lasnier, B., Wery, J., 2002. Mexican Gem Opals : nano- and micro-structure, origin of colour, comparison with other common opals of gemological significance. Aust. Gemol. 21, 230-233.

Fritsch, E., Rondeau, B., Ostroumov, M., Lasnier, B., Marie, A.-M., Barrault, A., Wery, J., Connoué, J., Lefrant, S., 1999. Découvertes récentes sur l’opale. Rev. Gemmol. A.F.G 138/139, 34-40.

Frydenvang, J., Gasda, P.J., Hurowitz, J.A., Grotzinger, J.P., Wiens, R.C., Newsom, H.E., Edgett, K.S., Watkins, J., Bridges, J.C., Maurice, S., Fisk, M.R., Johnson, J.R., Rapin, W., Stein, N.T., Clegg, S.M., Schwenzer, S.P., Bedford, C.C., Edwards, P., Mangold, N., Cousin, A., Anderson, R.B., Payré, V., Vaniman, D., Blake, D.F., Lanza, N.L., Gupta, S., Van Beek, J., Sautter, V., Meslin, P.-Y., Rice, M., Milliken, R., Gellert, R., Thompson, L., Clark, B.C., Sumner, D.Y., Fraeman, A.A., Kinch, K.M., Madsen, M.B., Mitrofanov, I.G., Jun, I., Calef, F., Vasavada, A.R., 2017. Diagenetic silica enrichment and latestage groundwater activity in Gale crater, Mars. Geophys. Res. Lett. 1-9. https://doi. org/10.1002/2017GL073323.

Gaillou, E., Delaunay, A., Rondeau, B., Bouhnik-le-Coz, M., Fritsch, E., Cornen, G., Monnier, C., 2008. The geochemistry of gem opals as evidence of their origin. Ore Geol. Rev. 34, 113-126. https://doi.org/10.1016/j.oregeorev.2007.07.004.

Gaj, M., Beyer, M., Koeniger, P., Wanke, H., Hamutoko, J., Himmelsbach, T., 2016. In situ unsaturated zone water stable isotope $\left({ }^{2} \mathrm{H}\right.$ and $\left.{ }^{18} \mathrm{O}\right)$ measurements in semi-arid environments: a soil water balance. Hydrol. Earth Syst. Sci. 20, 715-731. https://doi. org/10.5194/hess-20-715-2016.

Galeotti, S., DeConto, R., Naish, T., Stocchi, P., Florindo, F., Pagani, M., Barrett, P., Bohaty, S.M., Lanci, L., Pollard, D., Sandroni, S., Talarico, F.M., Zachos, J.C., 2016. Antarctic Ice Sheet variability across the Eocene-Oligocene boundary climate transition. Science 352, 76-80. https://doi.org/10.1126/science.aab0669.

Gallacher, A.D., 2001. Geochemistry of sedimentary opal, Hebel, Southern Queensland.
University of Melbourne. PhD thesis

García Massini, J.L.L., Jacobs, B.F., Massini, J.L.G., 2011. The effects of volcanism on Oligocene-age plant communities from the Ethiopian Plateau, and implications for vegetational resilience in a heterogeneous landscape. Rev. Palaeobot. Palynol. 164, 211-222. https://doi.org/10.1016/j.revpalbo.2010.12.003.

Gat, J.R., 1996. Oxygen and hydrogen isotopes in the hydrologic cycle. Annu. Rev. Earth Planet Sci. 24, 225-262.

Gislason, S.R., Arnorsson, S., Armannsson, H., 1996. Chemical weathering of basalt in Southwest Iceland; effects of runoff, age of rocks and vegetative/glacial cover. Am. J. Sci. 296, 837-907. https://doi.org/10.2475/ajs.296.8.837.

Giuliani, G., Fallick, A.E., Boyce, A.J., Pardieu, V., Pham, V.L., 2017. Pink and red spinels in marble: Trace elements, oxygen isotopes, and sources. Can. Mineral. 55, 743-761. https://doi.org/10.3749/canmin.1700009.

Goryniuk, M.C., Rivard, B.A., Jones, B., 2004. The reflectance spectra of opal-A (0.5-25 $\mu \mathrm{m})$ from the Taupo Volcanic Zone: Spectra that may identify hydrothermal system on planetary surfaces. Geophys. Res. Lett. 31, L24701. https://doi.org/10.1029/ 2004 GL021481.

Götze, J., Pan, Y., Müller, A., Kotova, E., Cerin, D., 2017. Trace Element Compositions and Defect Structures of High-Purity Quartz from the Southern Ural Region, Russia. Minerals 7, 189. https://doi.org/10.3390/min7100189.

Gübelin, E., 1986. Opal from Mexico. Aust. Gemol. 16, 45-51.

Hailemichael, M., Aronson, J.L., Savin, S., Tevesz, M.J., Carter, J.G., 2002. $\delta^{18}$ O in mollusk shells from Pliocene Lake Hadar and modern Ethiopian lakes: implications for history of the Ethiopian monsoon. Palaeogeogr. Palaeoclimatol. Palaeoecol. 186, 81-99. https://doi.org/10.1016/S0031-0182(02)00445-5.

Harris, S.J., Graham, I.T., Lay, A., Powell, W., Belousova, E., Zappettini, E., 2017. Trace element geochemistry and metasomatic origin of alluvial sapphires from the Orosmayo region, Jujuy province, northwest Argentina. Can. Mineral. 55, 595-617. https://doi.org/10.3749/canmin.1700015.

Heier, K.S., 1962. Trace elements in feldspars - A review. Norks Geol. Tidsskr. 42, 415-454.

Hein, J.R., Koschinsky, A., Halbach, P., Manheim, F.T., Bau, M., Kang, J.-K., Lubick, N., 1997. Iron and manganese mineralization in the Pacific. In: Manganese Mineralization: Geochemistry and Mineralogy of Terrestrial and Marine Deposits. Geol. Soc. Spec. Publ. No, vol. 119. pp. 123-138.

Hein, J.R., Scholl, D.W., Barron, J.A., Jones, M.G., Miller, J., 1978. Diagenesis of late Cenozoic diatomaceous deposits and formation of the bottom simulating reflector in the southern Bering Sea. Sedimentology 25, 155-181. https://doi.org/10.1111/j. 1365-3091.1978.tb00307.x.

Henderson, J.H., Jackson, M.L., Syers, J.K., Rex, R.W., 1971. Cristobalite authigenic origin in relation to montmorillonite and quartz origin in bentonites. Clay Clay Miner. 19, 229-238.

Herdianita, N.R., Browne, P.R.L., Rodgers, K.A., Campbell, K.A., 2000. Mineralogical and textural changes accompanying ageing of silica sinter. Miner. Deposits 35, 48-62. https://doi.org/10.1007/s001260050005.

Herzig, P.M., Becker, K.P., Stoffers, P., Bäcker, H., Blum, N., 1988. Hydrothermal silica chimney fields in the Galapagos Spreading Center at $86^{\circ} \mathrm{W}$. Earth Planet. Sci. Lett. 89, 261-272. https://doi.org/10.1016/0012-821X(88)90115-X.

Hofmann, C., Courtillot, V., Féraud, G., Rochette, P., Yirgu, G., Ketefo, E., Pik, R., 1997. Timing of the Ethiopian flood basalt event and implications for plume birth and global change. Nature 389, 838-841. https://doi.org/10.1038/39853.

IAEA/WMO, 2017. Global Network of Isotopes in Precipitation. The GNIP Database.

Icenhower, J.P., London, D., 1996. Experimental partitioning of Rb, Cs, Sr, and Ba between alkali feldspar and peraluminous melt. Am. Mineral. 81, 719-734.

Iler, R.K., 1979. Silica in Biology. The Chemistry of Silica 730-801.

Jackson, M.L., 1977. Cristobalite morphology and oxygen isotopic composition variation under hydrothermal alteration. Clay Clay Miner. 25, 31-38. https://doi.org/10. 1346/CCMN.1977.0250106.

Jacobs, B.F., Tabor, N., Feseha, M., Pan, A., Kappelman, J.W., Rasmussen, T., Sanders, W.J., Wiemann, M., Crabaugh, J., Massini, J.L.G., Leandro, J., Massini, G., 2005. Oligocene terrestrial strata of northwestern Ethiopia: a preliminary report on paleoenvironments and paleontology. Palaeontol. Electron. 8, 19.

Jones, B., Renaut, R.W., 2004. Water content of opal-A: implications for the origin of laminae in geyserite and sinter. J. Sediment. Res. 74, 117-128. https://doi.org/10 1306/052403740117.

Jones, B., Renaut, R.W., 2003. Hot spring and geyser sinters: the integrated product of precipitation, replacement, and deposition. Can. J. Earth Sci. 40, 1549-1569. https:// doi.org/10.1139/e03-078.

Jones, J.B., Segnit, E.R., 1971. Nature of Opal Part I: Nomenclature and constituent phases. J. Geol. Soc. Aust. 18, 57-68. https://doi.org/10.1080/ 00167617108728743

Juillet-Leclerc, A., Labeyrie, L., 1987. Temperature dependence of the oxygen isotopic fractionation between diatom silica and water. Earth Planet. Sci. Lett. 84, 69-74. https://doi.org/10.1016/0012-821X(87)90177-4.

Kebede, S., Travi, Y., 2012. Origin of the $\delta^{18} \mathrm{O}$ and $\delta^{2} \mathrm{H}$ composition of meteoric waters in Ethiopia. Quat. Int. 257, 4-12. https://doi.org/10.1016/j.quaint.2011.09.032.

Keith, T.E.C., Muffler, L.J.P., 1978. Minerals produced during cooling and hydrothermal alteration of ash flow tuff from Yellowstone drill hole Y-5. J. Volcanol. Geoth. Res. 3, 373-402. https://doi.org/10.1016/0377-0273(78)90044-6.

Keith, T.E.C., White, D.E., Beeson, M.H., 1978. Hydrothermal alteration and self-sealing in Y-7 and Y-8 drill holes in northern part of Upper Geyser Basin, Yellowstone National Park, Wyoming, U.S. Geol. Surv. Prof. Pap. 1054-A, 26.

Knauth, L.P., Epstein, S., 1982. The nature of water in hydrous silica. Am. Mineral. 67, 510-520.

Knauth, L.P., Epstein, S., 1976. Hydrogen and oxygen isotope ratios in nodular and bedded cherts. Geochem. Cosmochim. Acta 40, 1095-1108. https://doi.org/10. 
1016/0016-7037(76)90051-X.

Lalou, C., 1991. Deep-sea hydrothermal venting: A recently discovered marine system. J. Mar. Syst. 1, 403-440. https://doi.org/10.1016/0924-7963(91)90007-H.

Langer, K., Flörke, O.W., 1974. Near infrared absorption spectra $\left(4000-9000 \mathrm{~cm}^{-1}\right)$ of opals and the role of "water" in these $\mathrm{SiO}_{2}-\mathrm{nH}_{2} \mathrm{O}$ minerals. Fortschr. Mineral. 52, $17-51$.

Laveuf, C., Cornu, S., 2009. A review on the potentiality of Rare Earth Elements to trace pedogenetic processes. Geoderma 154, 1-12. https://doi.org/10.1016/j.geoderma. 2009.10.002.

Levin, N.E., Quade, J., Simpson, S.W., Semaw, S., Rogers, M., 2004. Isotopic evidence for Plio-Pleistocene environmental change at Gona, Ethiopia. Earth Planet. Sci. Lett. 219, 93-110. https://doi.org/10.1016/S0012-821X(03)00707-6.

Leybourne, M.I., Goodfellow, W.D., Boyle, D.R., Hall, G.M., 2000. Rapid development of negative Ce anomalies in surface waters and contrasting REE patterns in groundwaters associated with $\mathrm{Zn}-\mathrm{Pb}$ massive sulphide deposits. Appl. Geochem. 15, 695-723. https://doi.org/10.1016/S0883-2927(99)00096-7.

Liesgang, M., Milke, R., 2014. Australian sedimentary opal-A and its associated minerals : Implications for natural silica sphere formation. Am. Mineral. 99, 1488-1499.

Liu, W., Liu, W., Li, P., Duan, W., Li, H., 2010. Dry season water uptake by two dominant canopy tree species in a tropical seasonal rainforest of Xishuangbanna, SW China. Agric. For. Meteorol. 150, 380-388. https://doi.org/10.1016/j.agrformet.2009.12. 006.

Lynne, B.Y., Campbell, K.A., 2004. Morphologic and Mineralogic Transitions From OpalA to Opal-CT in Low-Temperature Siliceous Sinter Diagenesis, Taupo Volcanic Zone, New Zealand. J. Sediment. Res. 74, 561-579. https://doi.org/10.1306/ 011704740561.

Lynne, B.Y., Campbell, K.A., Moore, J.N., Browne, P.R.L., 2005. Diagenesis of 1900-yearold siliceous sinter (opal-A to quartz) at Opal Mound, Roosevelt Hot Springs, Utah. U.S.A. Sediment. Geol. 179, 249-278. https://doi.org/10.1016/j.sedgeo.2005.05. 012

Ma, L., Jin, L., Brantley, S.L., 2011. How mineralogy and slope aspect affect REE release and fractionation during shale weathering in the Susquehanna/Shale Hills Critical Zone Observatory. Chem. Geol. 290, 31-49. https://doi.org/10.1016/j.chemgeo. 2011.08.013.

Manley, C.R., 1992. Extended cooling and viscous flow of large, hot rhyolite lavas: implications of numerical modeling results. J. Volcanol. Geoth. Res. 53, 27-46. https:// doi.org/10.1016/0377-0273(92)90072-L.

Martin, E., Gaillou, E., 2018. Insight on gem opal formation in volcanic ash deposits from a supereruption: A case study through oxygen and hydrogen isotopic composition of opals from Lake Tecopa, California. U.S.A. Am. Mineral. 103, 803-811. https://doi. org/10.2138/am-2018-6131.

Massini, J.L.G., Jacobs, B.F., Tabor, N.J., 2010. Paleobotany and Sedimentology of Late Oligocene Terrestrial Strata From the Northwestern Ethiopian Plateau. Palaeontol. Electron. 13, 1-51. https://doi.org/Artn 6a.

Matyskiela, W., 1997. Silica redistribution and hydrologic changes in heated fractured tuff. Geology 25 (1115) 025 < 1115:SRAHCI > 2.3.CO;2. https://doi.org/10.1130/ 0091-7613(1997).

Mazzero, F., Désaglier, C., Rondeau, B., Ayalew, D., Ezezew, G., Cenki, T., Bekele, E, Wollo, L., Rondeau, B., Ayalew, D., 2010. L'opale du Wollo, Éthiopie: des mines de gisement. Rev. Gemmol. A.F.G 174, 14-20.

McDonough, W.F., Sun, S.-S., 1995. The composition of the Earth. Chem. Geol. 120, 223-253. https://doi.org/10.1016/0009-2541(94)00140-4.

McDougall, I., Morton, W.H., Williams, M.A.J., 1975. Age and rates of denudation of Trap Series basalts at Blue Nile Gorge, Ethiopia. Nature 254, 207-209. https://doi.org/10. 1038/254207a0.

McOrist, G.D., Smallwood, A.G., Fardy, J.J., 1994. Trace elements in Australian opals using neutron activation analysis. J. Radioanal. Nucl. Chem. 185, 293-303.

McOrist, G.D.D., Smallwood, A.G., 1997. Trace elements in precious and common opals using neutron activation analysis. J. Radioanal. Nucl. Chem. 223, 9-15. https://doi. org/10.1007/BF02223356.

Menicucci, A.J., Spero, H.J., Matthews, J., Parikh, S.J., 2017. Influence of exchangeable oxygen on biogenic silica oxygen isotope data. Chem. Geol. 466, 710-721. https:// doi.org/10.1016/j.chemgeo.2017.07.020.

Meunier, J.D., Colin, F., Alarcon, C., 1999. Biogenic silica storage in soils. Geology 27 (835). https://doi.org/10.1130/0091-7613(1999)027<0835:BSSIS > 2.3.CO;2

Milliken, R.E., Swayze, G.A., Arvidson, R.E., Bishop, J.L., Clark, R.N., Ehlmann, B.L. Green, R.O., Grotzinger, J.P., Morris, R.V., Murchie, S.L., Mustard, J.F., Weitz, C., 2008. Opaline silica in young deposits on Mars. Geology 36, 847. https://doi.org/10. 1130/G24967A.1.

Mizota, C., Toh, N., Matsuhisa, Y., 1987. Origin of cristobalite in soils derived from volcanic ash in temperate and tropical regions. Geoderma 39, 323-330. https://doi. org/10.1016/0016-7061(87)90051-6.

Moffett, J.W., 1990. Microbially mediated cerium oxidation in sea water. Nature 345, 421-423. https://doi.org/10.1038/345421a0.

Mohr, P., 1983. Ethiopian flood basalt province. Nature 303, 577-584. https://doi.org/ 10.1038/303577a0.

Monecke, T., Kempe, U., Götze, J., 2002. Genetic significance of the trace element content in metamorphic and hydrothermal quartz: a reconnaissance study. Earth Planet. Sci. Lett. 202, 709-724. https://doi.org/10.1016/S0012-821X(02)00795-1.

Morse, S.A., Allaz, J., 2013. Experimental partitioning of Sr and Ba in Kiglapait feldspars. Am. Mineral. 98, 2197-2200. https://doi.org/10.2138/am.2013.4630.

Murata, K.J., Friedman, I., Gleason, J.D., 1977. Oxygen isotope relations between diagenetic silica minerals in Monterey Shale, Temblor Range, California. Am. J. Sci. 277, 259-272. https://doi.org/10.2475/ajs.277.3.259.

Murata, K.J., Randall, R.G., 1975. Silica mineralogy and structure of the Monterey Shale, Temblor Range, California. J. Res. U. S. Geol. Surv. 3, 567-572.
Mustard, J.F., Murchie, S.L., Pelkey, S.M., Ehlmann, B.L., Milliken, R.E., Grant, J.A., Bibring, J.-P., Poulet, F., Bishop, J.L., Noe Dobrea, E.Z., Roach, L., Seelos, F.P., Arvidson, R.E., Wiseman, S., Green, R., Hash, C., Humm, D., Malaret, E., McGovern, J.A., Seelos, K., Clancy, T., Clark, R., Des Marais, D.J., Izenberg, N., Knudson, A., Langevin, Y., Martin, T., McGuire, P., Morris, R., Robinson, M., Roush, T., Smith, M., Swayze, G., Taylor, H., Titus, T., Wolff, M., 2008. Hydrated silicate minerals on Mars observed by the Mars Reconnaissance Orbiter CRISM instrument. Nature 454, 305-309. https://doi.org/10.1038/nature07097.

Nagasawa, H., 1971. Partitioning of $\mathrm{Eu}$ and $\mathrm{Sr}$ between coexisting plagioclase and Kfeldspar. Earth Planet. Sci. Lett. 13, 139-144. https://doi.org/10.1016/0012-821X (71)90116-6.

Nesbitt, H.W., 1979. Mobility and fractionation of rare earth elements during weathering of a granodiorite. Nature 279, 206-210. https://doi.org/10.1038/279206a0.

Ostrooumov, M., Fritsch, E., Lasnier, B., Lefrant, S., 1999. Spectres Raman des opales: aspect diagnostique et aide à la classification. Eur. J. Mineral. 11, 899-908.

Panahi, A., Young, G.M., Rainbird, R.H., 2000. Behavior of major and trace elements (including REE) during Paleoproterozoic pedogenesis and diagenetic alteration of an Archean granite near Ville Marie, Québec, Canada. Geochem. Cosmochim. Acta 64, 2199-2220. https://doi.org/10.1016/S0016-7037(99)00420-2.

Pédrot, M., Dia, A., Davranche, M., Gruau, G., 2015. Upper soil horizons control the rare earth element patterns in shallow groundwater. Geoderma 239-240, 84-96. https:// doi.org/10.1016/j.geoderma.2014.09.023.

Pik, R., Deniel, C., Coulon, C., Yirgu, G., Hofmann, C., Ayalew, D., 1998. The northwestern Ethiopian Plateau flood basalts: Classification and spatial distribution of magma types. J. Volcanol. Geoth. Res. 81, 91-111. https://doi.org/10.1016/S0377. 0273(97)00073-5.

Pik, R., Marty, B., Carignan, J., Lavé, J., 2003. Stability of the Upper Nile drainage network (Ethiopia) deduced from (U-Th)/He thermochronometry: implications for uplift and erosion of the Afar plume dome. Earth Planet. Sci. Lett. 215, 73-88. https:// doi.org/10.1016/S0012-821X(03)00457-6.

Pisciotto, K.A., 1981. Diagenetic trends in the siliceous facies of the Monterey Shale in the Santa Maria region, California. Sedimentology 28 574-571. https://doi.org/10. 1111/j.1365-3091.1981.tb01701.x.

Rey, P.F., 2013. Opalisation of the Great Artesian Basin (central Australia): an Australian story with a Martian twist. Aust. J. Earth Sci. 60, 291-314.

Rice, M.S., Cloutis, E.A., Bell, J.F., Bish, D.L., Horgan, B.H., Mertzman, S.A., Craig, M.A., Renaut, R.W., Gautason, B., Mountain, B., 2013. Reflectance spectra diversity of silica-rich materials: Sensitivity to environment and implications for detections on Mars. Icarus 223, 499-533. https://doi.org/10.1016/j.icarus.2012.09.021.

Rice, S.B., Freund, H., Huang, W.-L., Clouse, J.A., Isaacs, C.M., 1995. Application of Fourier Transform Infrared Spectroscopy to Silica Diagenesis: The Opal-A to Opal-CT Transformation. SEPM J. Sediment. Res. 65A, 639-647. https://doi.org/10.1306/ D4268185-2B26-11D7-8648000102C1865D.

Robert, F., Chaussidon, M., 2006. A palaeotemperature curve for the Precambrian oceans based on silicon isotopes in cherts. Nature 443, 969-972. https://doi.org/10.1038/ nature 05239 .

Rochette, P., Tamrat, E., Féraud, G., Pik, R., Courtillot, V., Ketefo, E., Coulon, C., Hoffmann, C., Vandamme, D., Yirgu, G., 1998. Magnetostratigraphy and timing of the Oligocene Ethiopian traps. Earth Planet. Sci. Lett. 164, 497-510. https://doi.org/ 10.1016/S0012-821X(98)00241-6.

Rodgers, K.A., Browne, P.R.L., Buddle, T.F., Cook, K.L., Greatrex, R.A., Hampton, W.A., Herdianita, N.R., Holland, G.R., Lynne, B.Y., Martin, R., Newton, Z., Pastars, D. Sannazarro, K.L., Teece, C.I.A., 2004. Silica phases in sinters and residues from geothermal fields of New Zealand. Earth Sci. Rev. 66, 1-61. https://doi.org/10.1016/ j.earscirev. 2003.10.001.

Rodgers, K.A., Cook, K.L., Browne, P.R.L., Campbell, K.A., 2002. The mineralogy, texture and significance of silica derived from alteration by steam condensate in three New Zealand geothermal fields. Clay Miner. 37, 299-322. https://doi.org/10.1180/ 0009855023720035 .

Rondeau, B., Cenki-Tok, B., Fritsch, E., Mazzero, F., Gauthier, J.-P., Bodeur, Y., Bekele, E., Gaillou, E., Ayalew, D., 2012. Geochemical and petrological characterization of gem opals from Wegel Tena, Wollo, Ethiopia: opal formation in an Oligocene soil. Geochem. Explor. Environ. Anal. 12, 93-104. https://doi.org/10.1144/1467-7873/ 10-MINDEP-058.

Rondeau, B., Fritsch, E., Guiraud, M., Renac, C., 2004. Opals from Slovakia ("Hungarian" opals): a re-assessment for the conditions of formation. Eur. J. Mineral. 16, 789-799. https://doi.org/10.1127/0935-1221/2004/0016-0789.

Rondeau, B., Fritsch, E., Mazzero, F., Gauthier, J.-P., Cenki-Tok, B., Bekele, E., Gaillou, E., Mazzero, F., Cenki-Tok, B., Bekele, E., Gaillou, E., 2010. Play-of-color opal from Wegel Tena, Wollo Province, Ethiopia. Gems Gemol. 46, 90-105.

Schmidt, P.W., Dickson, B.L., 2017. Paleomagnetic dating of ironstone nodules ('nuts') from the Yowah opal field, central southern Queensland. Aust. J. Earth Sci. 64, 743-752. https://doi.org/10.1080/08120099.2017.1355845.

Segnit, E.R., Stevens, T.J., Jones, J.B., 1965. The role of water in opal. J. Geol. Soc. Aust. $12,211-226$.

Seto, M., Akagi, T., 2008. Chemical condition for the appearance of a negative Ce anomaly in stream waters and groundwaters. Geochem. J. 42, 371-380. https://doi. org/10.2343/geochemj.42.371.

Sharp, Z.D., Gibbons, J.A., Maltsev, O., Atudorei, V., Pack, A., Sengupta, S., Shock, E.L., Knauth, L.P., 2016. A calibration of the triple oxygen isotope fractionation in the $\mathrm{SiO}_{2}-\mathrm{H}_{2} \mathrm{O}$ system and applications to natural samples. Geochem. Cosmochim. Acta 186, 105-119. https://doi.org/10.1016/j.gca.2016.04.047.

Smallwood, A.G., Thomas, P.S., Ray, A.S., 1997. Characterisation of sedimentary opals by Fourier transform Raman spectroscopy. Spectrochim. Acta Part A Mol. Biomol. Spectrosc. 53, 2341-2345. https://doi.org/10.1016/S1386-1425(97)00174-1.

Spencer, R.J., Levinson, A.A., Koivula, J.I., 1992. Opal from Quérétaro, Mexico: fluid 
inclusion study. Gems Gemol. 28, 28-34.

Squyres, S.W., Arvidson, R.E., Ruff, S., Gellert, R., Morris, R.V., Ming, D.W., Crumpler, L., Farmer, J.D., Des Marais, D.J., Yen, A., McLennan, S.M., Calvin, W., Bell, J.F., Clark, B.C., Wang, A., McCoy, T.J., Schmidt, M.E., De Souza, P.A.J., 2008. Detection of silica-rich deposits on Mars. Science 80 (320), 1063-1067. https://doi.org/10.1126/ science.1155429.

Summerfield, M.A., 1983. Silcrete as a palaeoclimatic indicator: evidence from southern Africa. Palaeogeogr. Palaeoclimatol. Palaeoecol. 41, 65-79. https://doi.org/10. 1016/0031-0182(83)90076-7.

Summerfield, M.A., 1979. Origin and palaeoenvironmental interpretation of sarsens. Nature 281, 137-139. https://doi.org/10.1038/281137a0.

Sutherland, F.L., Zaw, K., Meffre, S., Giuliani, G., Fallick, A.E., Graham, I.T., Webb, G.B., 2009. Gem-corundum megacrysts from east Australian basalt fields: Trace elements, oxygen isotopes and origins. Aust. J. Earth Sci. 56, 1003-1022. https://doi.org/10. 1080/08120090903112109.

Tanaka, K., Tani, Y., Takahashi, Y., Tanimizu, M., Suzuki, Y., Kozai, N., Ohnuki, T., 2010. A specific Ce oxidation process during sorption of rare earth elements on biogenic $\mathrm{Mn}$ oxide produced by Acremonium sp. strain KR21-2. Geochem. Cosmochim. Acta 74, 5463-5477. https://doi.org/10.1016/j.gca.2010.07.010.

Thiry, M., Millot, G., 1987. Mineralogical Forms of Silica and their Sequence of Formation in Silcretes. SEPM J. Sediment. Res. 57, 343-352. https://doi.org/10.1306/ 212F8B25-2B24-11D7-8648000102C1865D.

Thiry, M., Milnes, A.R., Rayot, V., Simon-Coinçon, R., 2006. Interpretation of palaeoweathering features and successive silicifications in the Tertiary regolith of inland Australia. J. Geol. Soc. London. 163, 723-736.

Thiry, M., Simon-Coinçon, R., 1996. Tertiary paleoweatherings and silcretes in the southern Paris Basin. Catena 26, 1-26.

Thiry, M.M., Milnes, A.R.R., 1991. Pedogenic and Groundwater Silcretes at Stuart Creek Opal Field, South Australia. SEPM J. Sediment. Res. 61, 111-127. https://doi.org/10. 1306/D426769F-2B26-11D7-8648000102C1865D.

Thomas, P.S., Brown, L.D., Ray, A.S., Prince, K.E., 2006. A SIMS study of the transition elemental distribution between bands in banded Australian sedimentary opal from the Lightning Ridge locality. Neues Jahrbuch Mineral. Abhand. 182, 193-199. https://doi.org/10.1127/0077-7757/2006/0044.

Thomas, P.S., Šesták, J., Heide, K., Fueglein, E., Šimon, P., 2010. Thermal properties of Australian sedimentary opals and Czech moldavites. J. Therm. Anal. Calorim. 99, 861-867. https://doi.org/10.1007/s10973-010-0706-z.

Tréguer, P., Nelson, D.M., Van Bennekom, A.J., DeMaster, D.J., Leynaert, A., Queguiner, B., 1995. The Silica Balance in the World Ocean: A Reestimate. Science 268, 375-379. https://doi.org/10.1126/science.268.5209.375.

Ukstins, I.A., Renne, P.R., Wolfenden, E., Baker, J., Ayalew, D., Menzies, M., 2002. Matching conjugate volcanic rifted margins: 40Ar/39Ar chrono-stratigraphy of preand syn-rift bimodal flood volcanism in Ethiopia and Yemen. Earth Planet. Sci. Lett. 198, 289-306. https://doi.org/10.1016/S0012-821X(02)00525-3.

Ullyott, J.S., Nash, D.J., Whiteman, C. a., Mortimore, R.N., 2004. Distribution, petrology and mode of development of silcretes (sarsens and puddingstones) on the eastern South Downs, UK. Earth Surf. Process. Landforms 29, 1509-1539. https://doi.org/10. 1002/esp.1136.

Viste, E., Korecha, D., Sorteberg, A., 2013. Recent drought and precipitation tendencies in Ethiopia. Theor. Appl. Climatol. 112, 535-551. https://doi.org/10.1007/s00704012-0746-3.

Vysotskiy, S.V., Ignatiev, A.V., Khlestunova, A.G., Velivetskaya, T.A., Okrugin, A.S., 2013. Peculiarities of the oxygen isotope ratio in precious opals. Russ. J. Pacific Geol. 7, 427-430. https://doi.org/10.1134/S1819714013060079.

Webb, J.A., Finlayson, B.L., 1987. Incorporation of Al, Mg, and water in opal-A: evidence from speleothems. Am. Mineral. 72, 1204-1210.

Weill, D.F., Drake, M.J., 1973. Europium Anomaly in Plagioclase Feldspar: Experimental Results and Semiquantitative Model. Science 180, 1059-1060. https://doi.org/10. 1126/science.180.4090.1059.

White, A.F., Buss, H.L., 2013. Natural Weathering Rates of Silicate Minerals, second ed Elsevier Inc Treatise on Geochemistry: Second Edition. https://doi.org/10.1016/ B978-0-08-095975-7.00504-0.

Zachos, J.C., Quinn, T.M., Salamy, K.A., 1996. High-resolution (100000 years) deep-sea foraminiferal stable isotope records of the Eocene-Oligocene climate transition. Paleoceanography 11, 251-266. 